\title{
Relating hygroscopicity and optical properties to chemical composition and structure of secondary organic aerosol particles generated from the ozonolysis of $\alpha$-pinene
}

\author{
C. Denjean ${ }^{1,2}$, P. Formenti ${ }^{1}$, B. Picquet-Varrault ${ }^{1}$, E. Pangui ${ }^{1}$, P. Zapf ${ }^{1}$, Y. Katrib ${ }^{1}$, C. Giorio ${ }^{3, *}$, A. Tapparo ${ }^{3}$, \\ A. Monod ${ }^{4}$, B. Temime-Roussel ${ }^{4}$, P. Decorse ${ }^{5}$, C. Mangeney $^{5}$, and J. F. Doussin ${ }^{1}$ \\ ${ }^{1}$ Laboratoire Interuniversitaire des Systèmes Atmosphériques (LISA), UMR-CNRS 7583, Université Paris-Est-Créteil \\ (UPEC) et Université Paris Diderot (UPD), Institut Pierre Simon Laplace (IPSL), Créteil, France \\ ${ }^{2}$ Leibniz Institute for Tropospheric Research, Permoserstr. 15, 04318, Leipzig, Germany \\ ${ }^{3}$ Dipartimento di Scienze Chimiche, Università degli Studi di Padova, via Marzolo 1, 35131 Padova, Italy \\ ${ }^{4}$ Aix Marseille Université, CNRS, Laboratoire Chimie de l'Environnement (LCE), FRE 3416, 13331 Marseille, France \\ ${ }^{5}$ ITODYS, Université Paris Diderot, Sorbonne Paris Cité, CNRS UMR 7086, 15 rue J-A de Baif, 75013 Paris, France \\ *now at: Department of Chemistry, University of Cambridge, Lensfield road, CB2 1EW Cambridge, UK
}

Correspondence to: C. Denjean (denjean@tropos.de)

Received: 7 March 2014 - Published in Atmos. Chem. Phys. Discuss.: 28 April 2014

Revised: 11 February 2015 - Accepted: 25 February 2015 - Published: 25 March 2015

\begin{abstract}
Secondary organic aerosol (SOA) were generated from the ozonolysis of $\alpha$-pinene in the CESAM (French acronym for Experimental Multiphasic Atmospheric Simulation Chamber) simulation chamber. The SOA formation and aging were studied by following their optical, hygroscopic and chemical properties. The optical properties were investigated by determining the particle complex refractive index (CRI). The hygroscopicity was quantified by measuring the effect of relative humidity ( $\mathrm{RH}$ ) on the particle size (size growth factor, GF) and on the scattering coefficient (scattering growth factor, $f(\mathrm{RH})$ ). The oxygen to carbon atomic ratios $(\mathrm{O}: \mathrm{C})$ of the particle surface and bulk were used as a sensitive parameter to correlate the changes in hygroscopic and optical properties of the SOA composition during their formation and aging in CESAM.

The real CRI at $525 \mathrm{~nm}$ wavelength decreased from 1.43$1.60( \pm 0.02)$ to $1.32-1.38( \pm 0.02)$ during the SOA formation. The decrease in the real CRI correlated to the $\mathrm{O}: \mathrm{C}$ decrease from $0.68( \pm 0.20)$ to $0.55( \pm 0.16)$. In contrast, the GF remained roughly constant over the reaction time, with values of $1.02-1.07( \pm 0.02)$ at $90 \%( \pm 4.2 \%)$ RH. Simultaneous measurements of $\mathrm{O}: \mathrm{C}$ of the particle surface revealed that the SOA was not composed of a homogeneous mixture, but contained less oxidised species at the surface which
\end{abstract}

may limit water absorption. In addition, an apparent change in both mobility diameter and scattering coefficient with increasing RH from 0 to $30 \%$ was observed for SOA after $14 \mathrm{~h}$ of reaction. We postulate that this change could be due to a change in the viscosity of the SOA from a predominantly glassy state to a predominantly liquid state.

\section{Introduction}

Organic compounds are known to account for a large fraction of atmospheric aerosol, ranging between 20 and $90 \%$ of the total particle mass (Kanakidou et al., 2005). In particular, secondary organic aerosol (SOA), formed by the condensation of gas-phase oxidation products of volatile organic compounds (VOCs), is a major constituent of the total organic aerosol (Turpin and Huntzicker, 1995; Zhang et al., 2007). SOA size ranges from ten to hundreds of nanometres $(\mathrm{nm})$. Particles in this size range have long atmospheric lifetimes and scatter solar radiation. SOA can also change cloud's properties by acting as cloud condensation nuclei (CCN) (Saxena et al., 1995; Lohmann and Feichter, 2005; Novakov and Penner, 1993; RiveraCarpio et al., 1996; Matsumoto et al., 1997). 
There are large uncertainties in estimating the impact of SOA on climate due to their complexity and the limited range of measurements available (Kanakidou et al., 2005). SOA precursors produce a large number of oxidation products (Goldstein and Galbally, 2009), resulting in many possible chemical reaction pathways (de Gouw et al., 2005; Hallquist et al., 2009). In addition, during their lifetime in the atmosphere, SOA may undergo several physical and chemical aging processes altering their chemical composition (Kalberer et al., 2004; Baltensperger, 2005; Yasmeen et al., 2012) and size distribution (Andreae, 2009). As a result, atmospheric SOA contains many organic compounds with a large variety of structures, chain lengths, functionalities and degrees of oxidation (Kroll and Seinfeld, 2008; Jimenez et al., 2009). Therefore, SOA possess a wide range of hygroscopic and optical properties (Lambe et al., 2013; Suda et al., 2012).

In global climate models, the direct radiative effect of SOA is currently described by adopting a constant complex refractive index (CRI) and a single size growth factor (GF). Depending on the model, the adopted real part of the CRI at visible wavelengths ranges from 1.45 to 1.60 (Kinne et al., 2003; Pere et al., 2011; Zaveri et al., 2010). Some models assume that SOA weakly absorbs solar radiation, and set the imaginary part of the CRI near 0.006, while others ignore the absorption by SOA. Concerning hygroscopic properties, a size GF of SOA derived from limited available data is used (O’Donnell et al., 2011; Hoyle et al., 2009). However, field measurements shows that the hygroscopic and optical properties of SOA are not static and depend on their origin and transport in the atmosphere (Duplissy et al., 2010; Jimenez et al., 2009; Chang et al., 2010; Dinar et al., 2008). As a consequence, laboratory investigations have started to explore the change of SOA properties during their lifetime. The ozonolysis of $\alpha$-pinene ozonolysis is one of the most well-studied SOA systems ( $\alpha$-pinene- $\mathrm{O}_{3}$ SOA), as $\alpha$-pinene is a significant biogenic VOC in many regions, and its ozonolysis plays an important role in SOA formation (Hallquist et al., 2009; Griffin et al., 1999; Yu et al., 1999; Kavouras et al., 1998, 1999). $\alpha$-Pinene- $\mathrm{O}_{3}$ SOA is also generally considered as a model for many biogenic VOCs containing an endocyclic double bond (Guenther et al., 1995). Saathoff et al. (2003) conducted experiments of $\alpha$-pinene- $\mathrm{O}_{3}$ SOA in a simulation chamber and observed an increase of the GF at $90 \%$ relative humidity (RH) from 1.080 to 1.106. Cocker et al. (2001) also reported an increase of the GF at $85 \% \mathrm{RH}$ from 1.065 to 1.11 within $6 \mathrm{~h}$. In contrast, Warren et al. (2009) and Qi et al. (2010) reported a constant GF at $90 \%$ RH for $\alpha$-pinene$\mathrm{O}_{3}$ SOA over $6 \mathrm{~h}$ of reaction. Finally, an increase of the real CRI from 1.39 to 1.52 at $\lambda=532 \mathrm{~nm}$ during the formation of the $\alpha$-pinene- $\mathrm{O}_{3}$ SOA was reported by Kim et al. (2013). To date, none of the previous studies have simultaneously determined the hygroscopic and optical properties, and their evolution with the particle chemical composition during SOA formation and ageing.
To accurately quantify the SOA impacts on climate, it is critical to determine the hygroscopic behaviour of both the size distribution and optical properties as well as the dependence of these properties on the chemical composition. Atmospheric simulation chambers are powerful tools to study the physical, chemical, optical and hygroscopic properties of SOA and follow their changes along their life cycle by simulating their formation and aging due to oxidation and photolysis in the atmosphere (Meyer et al., 2008; Henry and Donahue, 2012; Tritscher et al., 2011). In this work, we take advantage of the long aerosol lifetime in the CESAM chamber (French acronym for Experimental Multiphasic Atmospheric Simulation Chamber; Wang et al., 2011) to set up formation and aging experiments of $\alpha$-pinene- $\mathrm{O}_{3}$ SOA in order to characterise the evolution of both the SOA optical properties and hygroscopicity. The objective is to examine the evolution of these physical properties and to relate them to the aerosol chemical composition.

\section{Methods}

Measurements have been conducted in the humiditycontrolled simulation chamber CESAM (Wang et al., 2011), which permits the study of the formation and aging of SOA over long periods of time, and under various relevant atmospheric conditions (temperature, relative humidity, pressure, gas-phase concentration, etc.).

Experiments were conducted to simultaneously measure different parameters:

- CRI at $\lambda=525 \mathrm{~nm}$, a specific wavelength in the midvisible; the complex refractive index (CRI, $m=n-i k$ ) is an important parameter to link the physical and chemical properties of the SOA and its ability to interact with radiation, allowing a description of the scattering and absorbing characteristics of SOA.

- GF, size growth factor, the ratio of the particle diameter at a given $\mathrm{RH}$ to the particle diameter at low $\mathrm{RH}$, for one selected size of particles; this parameter is used to characterise the hygroscopic properties of the SOA and thus it is an indicator of its ability to act as CCN.

- $f(\mathrm{RH})$, scattering growth factor, the ratio of the scattering coefficient $\left(\sigma_{\text {scat }}\right)$ at high $\mathrm{RH}$ to the $\sigma_{\text {scat }}$ at low $\mathrm{RH}$, for the entire size distribution; this parameter allows the study of the effect of water absorption on the scattering properties of SOA.

- O : C, the oxygen-to-carbon ratio, for both the bulk and the surface composition of the SOA; it is well known that particle composition, in particular that of the surface, strongly influences the water uptake ability of the particle and its CCN potential (McFiggans et al., 2006; Dusek et al., 2006; Hatch et al., 2008; Moussa et al., 2009; McIntire et al., 2010; Semeniuk et al., 2007; 


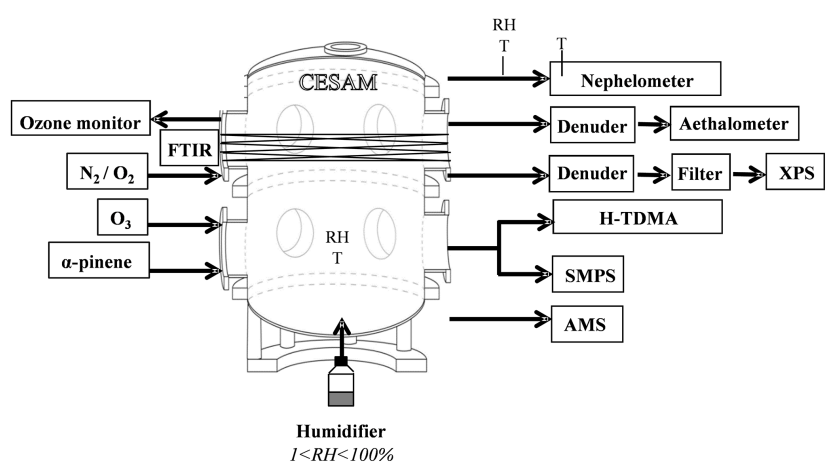

Figure 1. Experimental set-up of the CESAM chamber used to measure aerosol chemical, hygroscopic and optical properties.

Lamb et al., 2011; Wong et al., 2011; Mei et al., 2013; Rickards et al., 2013). To encompass the difficulty of representing the full molecular composition, the $\mathrm{O}: \mathrm{C}$ of SOA has been included in global climate models to provide a description of the aerosol aging (Tost and Pringle, 2012). Furthermore, a number of recent studies have reported a positive correlation between hygroscopicity and bulk $\mathrm{O}: \mathrm{C}$ for both laboratory and ambient SOA (Massoli et al., 2010; Jimenez et al., 2009; Chang et al., 2010; Duplissy et al., 2011).

\subsection{Simulation chamber and associated instruments}

CESAM is a $4.2 \mathrm{~m}^{3}$ cylindrical stainless steel chamber which has been designed to investigate both atmospheric gasphase and aerosol-phase chemistry. As described by Wang et al. (2011), the wall properties and ventilation system guarantee a lifetime for long sub-micron particles and enable the study of aerosol aging for more than $20 \mathrm{~h}$. Water vapour can be directly injected in CESAM and thus the RH of the reaction mixture can be varied in situ from 0 to $100 \%$.

The basic experimental set-up and a schematic view of the CESAM chamber are shown in Fig. 1. Temperature and relative humidity in the chamber are monitored using a Vaisala transmitter equipped with a capacitive thin-film HUMICAP sensor. The sensor was calibrated prior to each experiment. The accuracy of RH was \pm 1.9 up to $90 \% \mathrm{RH}$ and the temperature accuracy was $\pm 0.1{ }^{\circ} \mathrm{C}$ at $20^{\circ} \mathrm{C}$.

$\alpha$-Pinene, ozone and their reaction products were continuously monitored by a Fourier transform infrared spectrometer (FTIR) from Bruker GmbH (Ettlingen, Germany) coupled to a multi-reflection cell allowing an optical path of $192 \mathrm{~m}$. Additionally, ozone was monitored by a commercial HORIBA APOA 370 instrument (Kyoto, Japan) with a detection limit of $0.5 \mathrm{ppb}$ and a precision of $0.1 \mathrm{ppb}$.

The particle number size distribution was measured using a scanning mobility particle sizer (SMPS including a differential mobility analyzer (DMA) 3080 and condensation particle counter (CPC) 3010, TSI). The SMPS was operated at flow rates $3 / 0.3 \mathrm{~L} \mathrm{~min}^{-1}$ (sheath flow/aerosol sample flow). The aerosol flow was diluted with filtered air before entering the $\mathrm{CPC}$, in order to maintain the nominal flow rate at $1 \mathrm{~L} \mathrm{~min}^{-1}$ in the CPC. The dilution air flow was sucked from the simulation chamber to avoid any pressure gradient in the SMPS. The SMPS scanning time was $2 \mathrm{~min} 15 \mathrm{~s}$ in total. The resulting measured size distribution ranged from 14 to $505 \mathrm{~nm}$. The size calibration of the SMPS was performed using monodisperse PolyStyrene Latex spheres (PSL, Duke Scientific). PSL spheres, with diameters ranging from 100 to $500 \mathrm{~nm}$, were nebulised with a constant output atomiser (TSI model 3076). The measured diameters were found to be larger than the PSL certified diameters (by about $10 \%$ for $100 \mathrm{~nm}$ PSL spheres); therefore, a correction factor was applied. Size distributions were corrected by the SMPS software for both the loss by diffusion of particles in the SMPS tubing, the contribution of multi-charged particles and the dilution of the aerosol flow before entering the CPC.

\subsection{Optical properties measurements}

The aerosol scattering coefficient $\left(\sigma_{\text {scat }}\right)$ was measured using an integrating nephelometer (model M9003, Ecotech). The nephelometer operates at $525 \mathrm{~nm}$ wavelength and measures light scattered from particles at angles between 10 and $170^{\circ}$. It also measures temperature at both the sample inlet and within its cell with an accuracy of $\pm 0.6^{\circ} \mathrm{C}$, and the $\mathrm{RH}$ within its cell with an accuracy of $\pm 3 \%$. Prior to each series of experiments, the nephelometer was calibrated using particle-free air and $\mathrm{CO}_{2}$.

The particle light absorption coefficient $\left(\sigma_{\mathrm{abs}}\right)$ was determined by means of an aethalometer (model AE31, Magee Scientific) operated with several light sources at seven wavelengths, covering the near-ultraviolet to the near-infrared wavelength range $(\lambda=370,470,520,590,660,880$ and $950 \mathrm{~nm}$ ). The aethalometer measures the attenuation of the transmitted light through a quartz fibre filter with increasing particle loading. This measurement can suffer from artefacts associated with reactions with oxidants occurring on particles deposited on the surface of the filter and desorption of gaseous compounds from the filter (Weintgartner et al., 2003). Thus, a charcoal denuder was installed upstream of the aethalometer to remove ozone and VOCs. It has also been observed that the aethalometer can suffer from biases at high RH as a result of the filter taking up water and scattering more light compared to the reference measurement (Cappa et al., 2008; Arnott et al., 2005). Therefore, the aethalometer was not used when the chamber RH was higher than $1 \%$.

The spectral attenuation coefficient $\left(\sigma_{\text {attn }}\right)$ resulting from the attenuation of light through the sampled aerosol on the filter was obtained using Eq. (1):

$\sigma_{\mathrm{attn}}(\lambda, m)=\frac{A}{Q} \frac{\Delta \mathrm{attn}}{\Delta t}$, 
where $A$ is the spot area, $Q$ is the volumetric flow rate and $\Delta$ attn is the change in light attenuation during the time interval $\Delta t$. It is well known that $\sigma_{\text {attn }}$ obtained with an aethalometer is higher than true $\sigma_{\text {abs }}$ (Arnott et al., 2005; Bond et al., 1999; Bond and Bergstrom, 2006; Cappa et al., 2008; Collaud Coen et al., 2010; Weingartner et al., 2003). Various systematic errors need to be corrected. The detailed description of the method used to correct $\sigma_{\text {attn }}$ is shown in the Supplement.

The details of the calculations of CRI of SOA under dry conditions ( $\mathrm{RH}<1 \%)$ were given in Denjean et al. (2014). The CRI was determined by optical closure experiments involving scattering and absorption coefficients ( $\sigma_{\text {scat }}$ and $\sigma_{\text {abs }}$, respectively) measured at $525 \mathrm{~nm}$ and the number size distribution. Briefly, $\sigma_{\text {scat }}$ and $\sigma_{\text {abs }}$ were calculated according to Eq. (2)

$$
\begin{aligned}
& \sigma_{\text {scat, abs }}(\lambda, m)=\int Q_{\text {scat, abs }}\left(D_{\mathrm{p}}, \lambda, m\right) \frac{\pi}{4} D_{\mathrm{p}}^{2} \\
& \left(\frac{\mathrm{d} N}{\mathrm{~d} \log D_{\mathrm{p}}}\right) \mathrm{d} \log D_{\mathrm{p}},
\end{aligned}
$$

where $D_{\mathrm{p}}$ is the geometrical particle diameter, $\frac{\mathrm{d} N}{\mathrm{~d} \log D_{\mathrm{p}}}$ is the number size distribution and $Q_{\text {scat, abs }}\left(D_{\mathrm{p}}, \lambda, m\right)$ represent both the scattering and absorption efficiencies. $Q_{\text {scat,abs }}\left(D_{\mathrm{p}}, \lambda, m\right)$ were calculated using Mie scattering calculations described by Bohren and Huffman (1983).

The values of $\sigma_{\text {scat }}$ and $\sigma_{\text {abs }}$ of SOA were simultaneously measured and compared with those calculated based on the Mie theory. To allow this comparison, all measured $\sigma_{\text {scat }}$ were corrected from the sample temperature and pressure and from the angular truncation error examined for the nephelometer. The best-guess CRI was determined by minimising the difference between measured $\sigma_{\text {scat }}$ and $\sigma_{\text {abs }}$ and those obtained using Mie calculations.

\subsection{Hygroscopic properties measurements}

The hygroscopic properties of SOA were investigated using two complementary approaches as described in detail in Denjean et al. (2014). Briefly, (1) a hygroscopic tandem differential mobility analyzer (H-TDMA) was used to measure the $\mathrm{RH}$ dependency of the particles diameter for single size particles and (2) in situ experiments within the CESAM chamber allowed for the measurement of $\sigma_{\text {scat }}$ changes after water uptake for polydisperse aerosol size distribution.

The hygroscopic behaviour of monodisperse SOA was measured with a H-TDMA. The instrument is composed of a DMA (TSI, 3080) that selects an initial mobility diameter under dry conditions $D_{\mathrm{p}, \mathrm{m}}\left(\mathrm{RH}_{\mathrm{dry}}\right)$, an aerosol humidifier with a controlled higher RH and a DMA (TSI, 3080) coupled to a CPC (TSI, 3010) to measure the wet size distribution over mobility diameter $D_{\mathrm{p}, \mathrm{m}}(\mathrm{RH})$. The total sampling line used for H-TDMA measurements ranged between 10 and $20 \mathrm{~cm}$. Both DMAs of the H-TDMA were calibrated using monodisperse PSL particles (Duke Scientific) ranging from 100 to $500 \mathrm{~nm}$. A size shift was observed for both DMAs. The particles residence time for humidification is $15 \mathrm{~s}$ and corresponds to the residence time in the aerosol humidifier plus the transit time in the second DMA. In this study, the HTDMA was typically operated at a constant high $\mathrm{RH}( \pm 1 \%)$ of $90 \%$. The hygroscopic size growth factor (GF) describes the relative increase in the geometric diameter of particles due to water uptake at a specific RH according to Eq. (3):

$\mathrm{GF}(\mathrm{RH})=\frac{D_{\mathrm{p}, \mathrm{m}}(\mathrm{RH})}{D_{\mathrm{p}, \mathrm{m}}(40 \% \mathrm{RH})}$.

Due to possible changes in SOA viscosities (i.e. Sect. 4.2.), $\mathrm{RH}=40 \%$ was considered dry in this study. GF at $40 \%$ $\mathrm{RH}$ was measured at the beginning and the end of each series of H-TDMA measurements. Dry and humidified mobility diameters were obtained by assuming that the size distributions exhibited a log-normal profile. H-TDMA measurements were validated by measuring the humidogram of laboratory generated ammonium sulfate particles. The GF was found to agree with values calculated using the Köhler model (Denjean et al., 2014).

In addition to H-TDMA measurements, the hygroscopic behaviour of polydisperse SOA was measured by exposing the particles in situ to increasing humidity in the CESAM chamber. Water vapour produced from a small glass vessel filled with ultrapure water (18.2 M $\Omega$, ELGA Maxima) was injected into the chamber and mixed therein by the chamber's stainless steel fan. The RH in the chamber increased linearly from 0 to $100 \%$ within approximately $1 \mathrm{~h}$. The change in $\sigma_{\text {scat }}$ due to hygroscopic growth of the overall particle size distribution was monitored by the nephelometer. The scattering growth factor, $f(\mathrm{RH})$ is the ratio between the scattering coefficient at a specific $\mathrm{RH}, \sigma_{\text {scat }}(\mathrm{RH})$, and the dry scattering coefficient, $\sigma_{\text {scat }}($ dry) (Eq. 4):

$f(\mathrm{RH})=\frac{\sigma_{\text {scat }}(\mathrm{RH})}{\sigma_{\text {scat }}(40 \% \mathrm{RH})}$.

During humidification, $\mathrm{RH}$ was monitored within the chamber and at the inlet of the nephelometer. Using this approach, the residence time for particle humidification was a few minutes thus significantly longer than during H-TDMA measurements. It has been previously shown (Denjean et al., 2014) that the two approaches of hygroscopicity measurements could lead to different results, giving information on water transfer dynamics, possible particles reorganisation or phase transfer equilibrium.

\subsection{Aerosol sampling and chemical composition analysis}

A high-resolution time-of-flight aerosol mass spectrometer (AMS, Aerodyne) (DeCarlo et al., 2006) was used to determine the bulk composition of organic aerosols (Aiken et al., 
2007, 2008). The instrument was used under standard conditions (vaporiser at $600^{\circ} \mathrm{C}$ and electron ionisation at $70 \mathrm{eV}$ ). Standard AMS calibration procedures using $\mathrm{NH}_{4} \mathrm{NO}_{3}$ particles were performed throughout the campaign and included ionisation efficiency (IE) calibration using the brute force single particle (BFSP) method at $350 \mathrm{~nm}$ particle mobility diameter as well as size calibration using DMA-selected dried particle sizes over the range of interest, i.e. $100-350 \mathrm{~nm}$. Single ion calibration as well as baseline and threshold were analysed prior each experiment.

The AMS was operated during three experiments. The instrument was switched between two modalities: a singlereflectron configuration (V-mode) which offers a higher sensitivity and lower resolving power (up to $\sim 2100$ at $\mathrm{m} / z$ 200) and a double-reflectron configuration (W-mode) which provides a higher resolving power (up to $\sim 4300$ at $\mathrm{m} / \mathrm{z} 200$ ) but lower sensitivity (De Carlo et al., 2006). Data were taken with a time resolution of $8 \mathrm{~min}$. In V-mode, data were collected in the mass spectrum (MS) mode for $5 \mathrm{~min}$, for aerosol quantification, and in the particle time-of-flight (PToF) mode for $1 \mathrm{~min}$ for size distribution measurement (De Carlo et al., 2006, Canagaratna et al., 2007). Only MS data were recorded in the $\mathrm{W}$-mode ( $2 \mathrm{~min})$.

The AMS data were analysed using Squirrel (ToF-AMS Analysis 1.51B) and Pika (ToF-AMS high-resolution (HR) Analysis 1.10B) packages for the software Igor Pro 6.21 (Wavemetrics, Inc., Portland, OR, USA). Default collection efficiencies (CE) and relative ionisation efficiencies (RIE) were used for quantification of SOA. Air interferences were removed by adjusting the fragmentation table (Aiken et al., 2008; Allan et al., 2004). High-resolution analyses (De Carlo et al., 2006) were performed on V-mode data by integrating each CxHyOzion in the mass range $12-180 \mathrm{~m} / \mathrm{z}$, while $\mathrm{W}$ mode data were used only to check for possible interferences. Elemental ratios $(\mathrm{O}: \mathrm{C}$ and $\mathrm{H}: \mathrm{C})$ were calculated according to the procedure described by Aiken et al. (2007, 2008). Measurement uncertainties were estimated to be $\pm 30 \%$, as determined by Aiken et al. (2008).

Further chemical analyses were performed by collecting SOA on polytetrafluoroethylene (PTFE) filters (Zefluor, $47 \mathrm{~mm}$ diameter, $2 \mu \mathrm{m}$ pore size, Pall Life Sciences), which were cut to the size of the collector using ceramic scissors. A stainless steel support was used for sampling and concentrating the particles in a small filter area $\left(0.9 \mathrm{~mm}^{2}\right)$. An active charcoal denuder was installed upstream of the filter to remove ozone and VOCs. Before sampling, filters were extracted 3 times for $10 \mathrm{~min}$ with dichloromethane $(99.8 \%$, HPLC grade) in an ultrasonic bath and baked for $5 \mathrm{~h}$ at $250^{\circ} \mathrm{C}$. Filter samplings were performed in the chamber at different reaction times from $30 \mathrm{~min}$ to $17 \mathrm{~h}$ at a nominal flow rate of $2 \mathrm{~L} \mathrm{~min}^{-1}$ for a sampling time varying between $30 \mathrm{~min}$ to $2 \mathrm{~h}$, depending on the total SOA volume concentration.

X-ray photoelectron spectrometry (XPS) was used to quantify the $\mathrm{O}: \mathrm{C}$ of the SOA surface to a depth less than $10 \mathrm{~nm}$. Measurements were performed on a VG ESCALAB 250 instrument using monochromatic $\mathrm{Al} \mathrm{K}_{\alpha}$ radiation $(1486.6 \mathrm{eV})$. The X-ray spot size was $500 \mu \mathrm{m}$. The analysis chamber of the instrument was maintained at pressures ranging between $10^{-8}$ and $10^{-11}$ mbar. Survey spectra of SOA were measured over an $1100 \mathrm{eV}$ range at a resolution of $1 \mathrm{eV}$ per step and $100 \mathrm{eV}$ pass energy (Fig. S1a in the Supplement). All peaks were referred to the $\mathrm{C}_{1 \mathrm{~s}}$ binding energy at $285.0 \mathrm{eV}$. The high-resolution $\mathrm{C}_{1 \mathrm{~s}}$ spectrum showed the presence of $\mathrm{C}, \mathrm{O}$ and $\mathrm{F}$. The deconvolution of the $\mathrm{C}_{1 \mathrm{~s}}$ signal was performed in peaks corresponding to the $-\mathrm{CO}_{2}$ (indicative of carboxylic acids, peroxides), $\mathrm{C}-\mathrm{O}$ (alcohols, aldehydes, carboxylic acids, peroxides, ethers), $\mathrm{C}-\mathrm{C} / \mathrm{C}-\mathrm{H}$ (aliphatic functional groups) and the $\mathrm{C}-\mathrm{F}$ bonds of the PTFE filter in order to optimise the fit (Fig. S1b). Quantification of the O : C was performed using the integrated peak areas of $\mathrm{O}_{1 \mathrm{~s}}$ spectra, the peaks area of the $-\mathrm{CO}_{2}, \mathrm{C}-\mathrm{O}$ and $\mathrm{C}-\mathrm{C} / \mathrm{C}-\mathrm{H}$ from the $\mathrm{C}_{1 \mathrm{~s}}$ spectra and the manufacturer's sensitivity factors.

To exclude biases in the comparison of the surface and bulk $\mathrm{O}$ : $\mathrm{C}$ ratios by different experimental methods, a control experiment was performed on pinic acid which is a pure homogeneous compound containing multiple carbon-oxygen bonds and which is representative of $\alpha$-pinene- $\mathrm{O}_{3}$ SOA (theoretical $\mathrm{O}: \mathrm{C}$ value of 0.44$)$. $0.003 \mathrm{M}$ pinic acid solution (Santai Labs, purity by ${ }^{1} \mathrm{HNMR}$ of $>95 \%$ ) was atomised using a constant output atomiser (TSI, model 3076) and then passed through a Nafion tube, which reduced the $\mathrm{RH}$ below $35 \%$. Particles were analysed with the AMS and simultaneously collected on PTFE filters for XPS analysis. The O : C values obtained experimentally from this single measurement by AMS and XPS were $0.34( \pm 0.10)$ and $0.37( \pm 0.08)$, respectively, as expected for particles of homogeneous composition. In addition, both methods reproduced the expected molecular $\mathrm{O}: \mathrm{C}$ of pinic acid within the uncertainty range. This control experiment sets the reference case for the joint use of XPS and AMS to resolve compositional differences in non-homogenous SOA.

\subsection{Experimental protocol}

Experiments were carried out without any seed particles or $\mathrm{OH}$ radical scavenger. Prior to each experiment, the CESAM chamber was evacuated overnight to typically $4 \times 10^{-4}$ mbar. The chamber was then filled to atmospheric pressure with a mixture of 200 mbar of oxygen (Air Liquide, Alphagaz class 1, purity $99.9 \%$ ) and 800 mbar of nitrogen produced from the evaporation of a pressurised liquid nitrogen tank (Messer, purity $>99.995 \%, \mathrm{H}_{2} \mathrm{O}<5$ ppm). Table 1 shows the experimental conditions of this study. Ozone was generated by a Corona discharge in pure $\mathrm{O}_{2}$ using a commercial dielectric ozone generator (MBT 802N, Messtechnik GmbH, Stahnsdorf, Germany). After ozone concentration stabilisation around $250 \mathrm{ppb}$ in the chamber, approximately $200 \mathrm{ppb}$ of $\alpha$-pinene was introduced. This injection was performed by flushing into the chamber (in an $\mathrm{O}_{2}$ flow) 

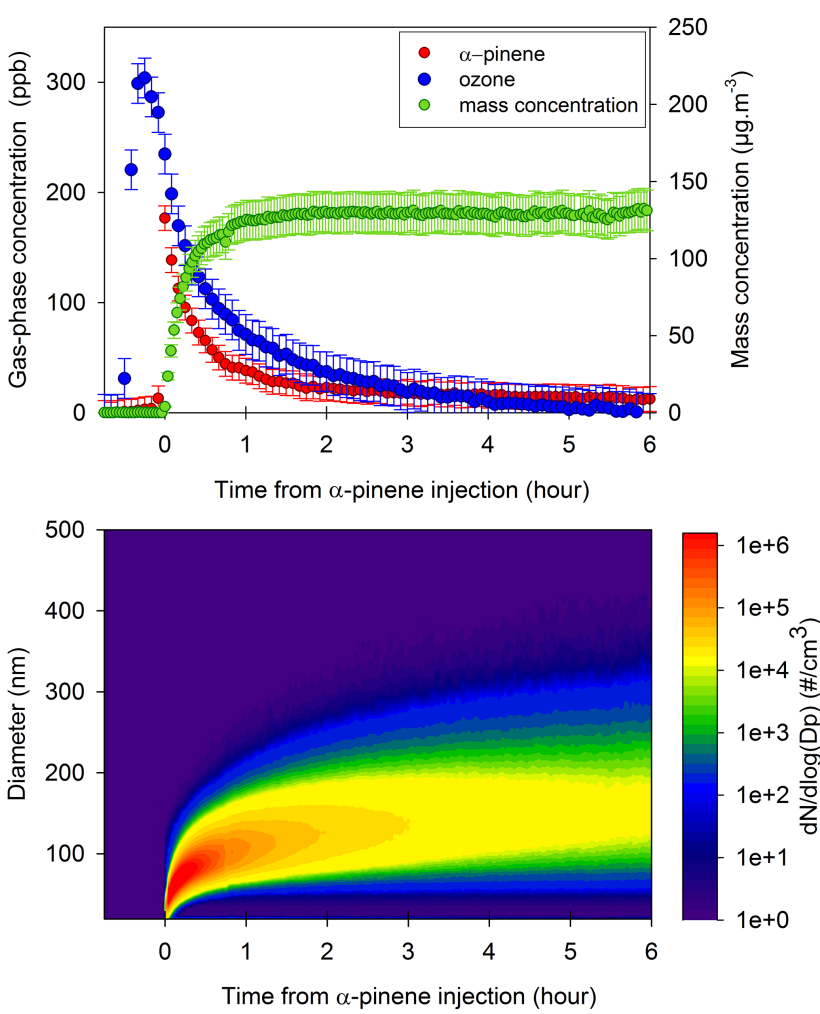

Figure 2. Temporal profiles of the initial phases of a typical $\alpha$ pinene ozonolysis experiment (E160410): (a) $\alpha$-pinene (red), ozone (blue) and mass concentration of the SOA (green) and (b) measured number size distribution.

ozone into the chamber, and due to the very fast consumption of $\alpha$-pinene, its initial concentration could not be accurately measured. For the yield calculations, we used the SOA mass concentration and $\alpha$-pinene concentration after $5 \mathrm{~min}$ of reaction as initial concentrations. SOA mass concentration was calculated from the SMPS number size distribution corrected for dilution and the measured particle density, assuming homogeneous spherical particles. The SOA density of $1.2 \mathrm{~g} \mathrm{~m}^{-3}$ was estimated from the mobility mode and aerodynamic mode obtained from the SMPS and AMS measurements, respectively, as described by DeCarlo et al. (2004) and Katrib et al. (2005). No significant change in the SOA density was found during the experiment. Furthermore, the retrieved value is in agreement with previous laboratory studies (Shilling et al., 2008; Saathoff et al., 2009). Table 1 shows that the SOA mass concentration of SOA varied from 44 to $139 \mathrm{\mu g} \mathrm{m}^{-3}$, resulting in calculated yields values ranging between 0.07 and 0.21 . The comparison between the steadystate aerosol yields determined in this study and the values reported in the literature is available in the Supplement (Fig. S2).

\subsection{Complex refractive index}

The real and imaginary parts of the CRI were retrieved to describe the scattering and absorbing characteristics of SOA.

The imaginary part of the CRI was estimated from the attenuation measurements obtained with the aethalometer. Since the attenuation coefficient depends on the quantity of particles accumulated on the filter, the CRI could not be calculated during the SOA formation, while the mass concentration increased rapidly until the $\alpha$-pinene was completely consumed. Figure S3 (Supplement) shows that the absorption coefficient in the $370-950 \mathrm{~nm}$ wavelength range estimated after $14 \mathrm{~h}$ of reaction is close to or below zero, indicating that the SOA do not absorb radiation in the visible to near-UV region. Therefore, the imaginary part of the CRI was set to zero. This result is consistent with previous studies on the absorbing properties of $\alpha$-pinene- $\mathrm{O}_{3}$ SOA. Cappa et al. (2008) observed no significant absorption of $\alpha$-pinene- $\mathrm{O}_{3}$ $\mathrm{SOA}$ at $532 \mathrm{~nm}$ with a photoacoustic spectrometer. Schnaiter et al. (2003) and Nakayama et al. (2010) measured no significant difference between scattering and extinction coefficient in the visible spectrum. Nakayama et al. (2012) showed that the imaginary part of the CRI values was negligible $(<0.003)$ in the 405-781 nm wavelengths. Recently, Liu et al. (2013) also reported an imaginary part of the CRI below $10^{-4}$ in the $355-781 \mathrm{~nm}$ wavelengths range.

Figure 3a shows the real part of the retrieved CRI at $525 \mathrm{~nm}$ as a function of reaction time. The real CRI were calculated when SOA exhibited a diameter high enough to allow for the detection of the full size distribution by the SMPS. Based on the measurement uncertainties of $\pm 10 \%$ for $\sigma_{\text {scatt }}$, we estimate an absolute error associated with the real CRI of \pm 0.02 . The real CRI decreased from $1.43-1.60$ at the beginning of the reaction to $1.32-1.38$ after $14 \mathrm{~h}$ of reaction. In contrast, no significant changes in the CRI were observed during the first hour of reaction for experiments E050210 and E080210. As shown in Fig. 3b, the aerosol mass concentrations in these experiments were stabilised after $20 \mathrm{~min}$ of reaction, which was significantly faster than in the other experiments. This may result from differences in the $[\mathrm{VOC}] /\left[\mathrm{O}_{3}\right]$ concentrations (see discussion in Sect. 3.1 on the initial concentrations of $\alpha$-pinene), leading to different reaction kinetics (Chan et al., 2007). The real CRI appears to change significantly in most of the experiments between $10 \mathrm{~min}$ and $1 \mathrm{~h}$ of reaction and it is possible that these variations were not detected in experiments E050210 and E080210. Values for the real part of the CRI retrieved in this study at $525 \mathrm{~nm}$ are compared with the literature values obtained for SOA produced during $\alpha$-pinene $+\mathrm{O}_{3}$ SOA formation (Table 2). Because our experiments were performed under various timescales and under various conditions and because our CRI values evolved with SOA aging, we can globally say that our values (1.321.60 ) were in the same range as the previous ones. 
Table 2. Comparison of size growth factor GF at $90 \% \mathrm{RH}$ of $\alpha$-pinene- $\mathrm{O}_{3}$ SOA with previous studies.

\begin{tabular}{|c|c|c|c|c|c|}
\hline Reference & Real CRI & $\begin{array}{l}\text { Residence } \\
\text { time }\end{array}$ & $\begin{array}{l}\lambda \\
(\mathrm{nm})\end{array}$ & $\begin{array}{l}{[\alpha \text {-pinene }]_{\text {initial }}} \\
(\mathrm{ppm})\end{array}$ & $\begin{array}{l}{\left[\mathrm{O}_{3}\right]_{\text {initial }}} \\
(\mathrm{ppm})\end{array}$ \\
\hline \multirow[t]{2}{*}{ This study } & $1.60( \pm 0.02)$ & $10 \mathrm{mn}$ & 525 & 0.20 & 0.25 \\
\hline & $1.33( \pm 0.02)$ & $19 \mathrm{~h}$ & & & \\
\hline Kim et al. (2010) & $1.45( \pm 0.05)$ & $2.5 \mathrm{~h}$ & 670 & $0.50-5.00$ & $0.10-1.00$ \\
\hline Kim and Paulson (2013) & $1.39-1.52( \pm 0.02)$ & $<30 \mathrm{mn} 4 \mathrm{~h}$ & 532 & $0.13-0.17$ & 0.50 \\
\hline Liu et al. (2013) & $1.498( \pm 0.002)$ & $38 \mathrm{~s}$ & 550 & 4.00 & 52.2 \\
\hline Nakayama et al. (2010) & $1.41( \pm 0.02)$ & $2-3 \mathrm{~h}$ & 532 & 0.10 & 2.00 \\
\hline Nakayama et al. (2012) & $1.47-1.48( \pm 0.02)$ & $2-3 \mathrm{~h}$ & 532 & 0.10 & $1.09-2.57$ \\
\hline Redmond and Thompson (2011) & $1.49( \pm 0.04)$ & - & 532 & - & $0.5-1.00$ \\
\hline Schnaiter et al. (2003) & 1.44 & $1.23 \mathrm{~h}$ & $>350$ & 0.06 & 0.47 \\
\hline Wex et al. (2009) & 1.45 & $2 \mathrm{mn}$ & visible & - & excess \\
\hline
\end{tabular}
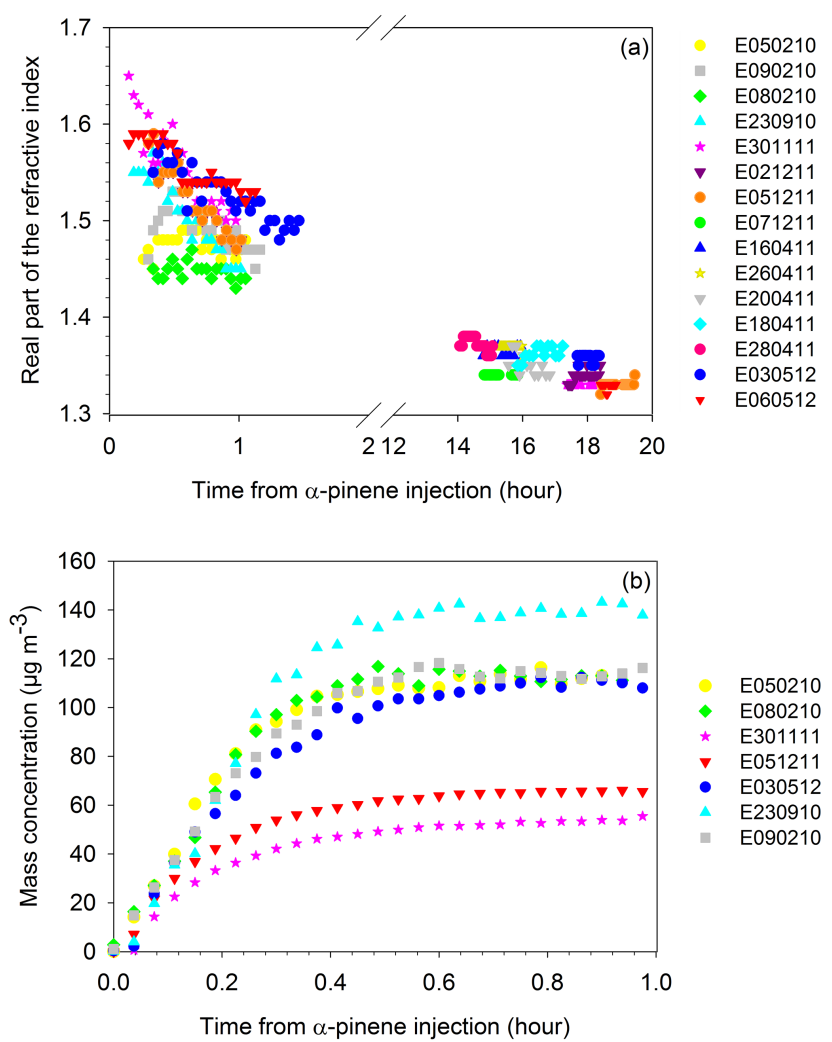

Figure 3. Calculated real part of the complex refractive index at $\lambda=525 \mathrm{~nm}$ of SOA as a function of the reaction time (upper panel). The lower panel shows the corresponding mass concentration for the initial formation phase after injection (estimated particle density set to $1.2 \mathrm{~g} \mathrm{~m}^{-3}$ ).

\subsection{Hygroscopic properties}

The first insight in the hygroscopic behaviour of SOA was brought by measuring humidograms of SOA with the $\mathrm{H}$ TDMA. Particles of $115 \mathrm{~nm}$ diameter were selected for the analysis after $2 \mathrm{~h}$ aging and $190 \mathrm{~nm}$ after $14 \mathrm{~h}$ aging. The GF uncertainty was estimated from the uncertainty in retrieving

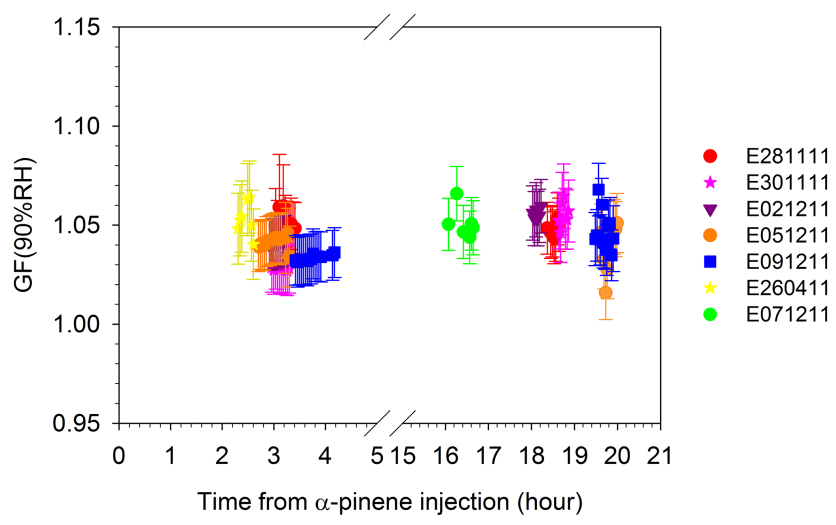

Figure 4. Size growth factor GF at $90 \% \mathrm{RH}$ obtained from the HTDMA measurement as a function of the reaction time. For the calculations of GF, we used $D_{\mathrm{p}, \mathrm{m}}\left(\mathrm{RH}_{\mathrm{dry}}\right)$ at $40 \% \mathrm{RH}$.

the geometric diameters and the RH uncertainty was based on the weighted average of the RH sensors uncertainties at the entrance of the H-TDMA. The GF values at $90 \% \mathrm{RH}$ of SOA are reported in Fig. 4 as a function of time. GF ranged from $1.02( \pm 0.02)$ to $1.07( \pm 0.02)$ at $90 \pm 4.2 \% \mathrm{RH}$ during and after SOA formation, in agreement with values previously reported in the literature (Table 3 ).

The comparison of the mobility diameter as a function of RH after 2 and $14 \mathrm{~h}$ of SOA aging is shown in Fig. 5a. Unusual behaviour of the mobility diameter and $f(\mathrm{RH})$ at the end of the experiment (at $t=16-20 \mathrm{~h}$ ) is evident. Mobility diameters dropped to a minimum between 20 and $50 \%$ $\mathrm{RH}$ for SOA after a $14 \mathrm{~h}$ reaction that was not observed for fresh SOA. Figure 5b shows the RH dependence of $f(\mathrm{RH})$ of the polydisperse size distribution as measured directly in the chamber during water injection after 1 and $16 \mathrm{~h}$ of the reaction. Two RH scales are used: one for the measurements performed within the chamber and the other for the measurements performed using the nephelometer. In fact, a small drying of $10 \%$ has been observed between the chamber and the nephelometer. No experiment with nephelometer mea- 
Table 3. Comparison of bulk $\mathrm{O}: \mathrm{C}$ of $\alpha$-pinene- $\mathrm{O}_{3}$ SOA with previous studies in the literature.

\begin{tabular}{lllll}
\hline Reference & GF $(90 \% \mathrm{RH})$ & Residence time & {$[\alpha \text {-pinene }]_{\text {initial }}(\mathrm{ppm})$} & {$\left[\mathrm{O}_{3}\right]_{\text {initial }}(\mathrm{ppm})$} \\
\hline This study & $1.02-1.07( \pm 0.02)$ & $2 \mathrm{~h}$ & 0.20 & 0.25 \\
& $1.02-1.07( \pm 0.02)$ & $20 \mathrm{~h}$ & & excess \\
Prenni et al. (2007) & $1.01-1.07( \pm 0.02)$ & $2 \mathrm{~h}$ & - & $0.30-0.34$ \\
Qi et al. (2010) & 1.09 & $30 \mathrm{mn}$ & $0.05-0.10$ & \\
& 1.09 & $7 \mathrm{~h}$ & & 0.5 \\
Saathoff et al. (2003) & $1.08( \pm 0.01)$ & $1 \mathrm{~h}$ & 0.06 & $0.3-0.5$ \\
& $1.11( \pm 0.01)$ & $6 \mathrm{~h}$ & & \\
Warren et al. (2009) & $1.02-1.16( \pm 0.02)$ & $30 \mathrm{mn}$ & 0.05 & \\
& $1.02-1.16( \pm 0.02)$ & $6 \mathrm{~h}$ & & \\
\hline
\end{tabular}
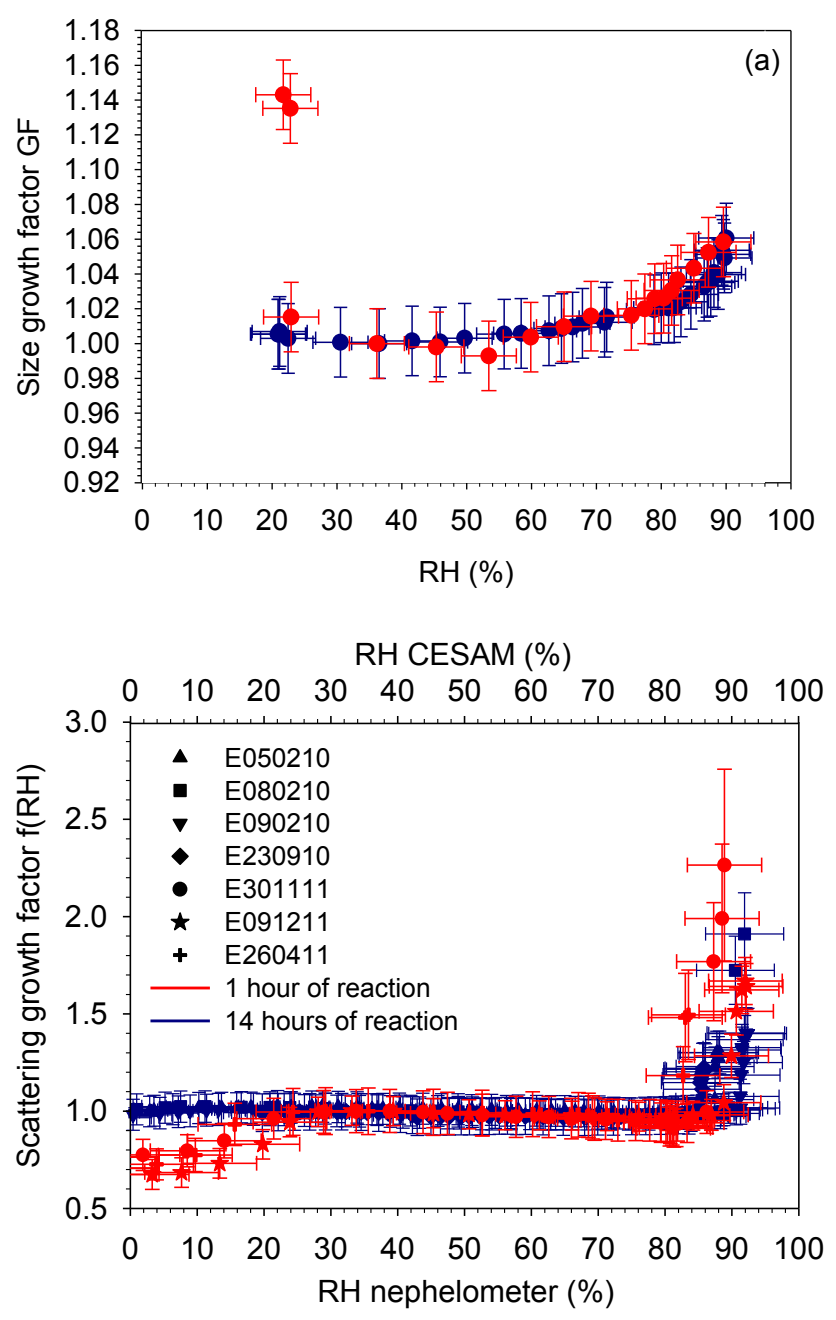

Figure 5. Humidograms of (a) size growth factor measured by the H-TDMA and (b) scattering growth factor measured by the nephelometer as a function of $\mathrm{RH}$ within the nephelometer (bottom axis) and the RH within the chamber (upper axis), for fresh SOA (after $1 \mathrm{~h}$ of reaction) in red and for aged SOA (after $14 \mathrm{~h}$ of reaction) in blue. For the calculations of $f(\mathrm{RH})$ and $\mathrm{GF}$, we used $\sigma_{\text {scat }}\left(\mathrm{RH}_{\mathrm{dry}}\right)$ and $D_{\mathrm{p}, \mathrm{m}}\left(\mathrm{RH}_{\mathrm{dry}}\right)$ at $40 \% \mathrm{RH}$. surements at the beginning and the end of the same date was available. However, the experiments were performed under very similar initial conditions as shown by the reproducible values of CRI and GF that are also comparable with each other. There is an initial increase of $f(\mathrm{RH})$ as $\mathrm{RH}$ increases from 0 to $30 \%$. This can be due to a change in the physical state of SOA. In fact, particles with irregular shapes or porous should be observed at higher mobility diameters in the DMA than spherical and compact particles of the same mass (De Carlo et al., 2004). After water uptake, the particles may become more spherical or compact, leading to a shift of the mobile size distribution measured with the DMA (Milkhailov et al., 2009). Particles are expected to also exhibit a higher mass concentration, and the $\sigma_{\text {scatt }}$ should increase after humidification (Adachi et al., 2011). This hypothesis is discussed in details in Sect. 4.2. A second slope is observed between 80 and $90 \% \mathrm{RH}$, linked to the sharp increase of GF due to particle water absorption. All the experiments exhibited the same trend, but different values are observed at $90 \% \mathrm{RH}$. This can be explained by the different size distributions from one experiment to another. In particular, the proportion of particles larger than $100 \mathrm{~nm}$ is different resulting in a different capacity in absorbing water (Biskos et al., 2006) and hence varying the observed $f(\mathrm{RH})$.

An important concern in measuring the hygroscopic properties of the particles is to allow sufficient time for particlewater vapour equilibrium. Various studies have discussed the possibility that insufficient time for humidification could result in an underestimation of the particles' water content (Chan and Chan, 2005; Saxena et al., 1995; Duplissy et al., 2009; Denjean et al., 2014). In this study, the residence time for SOA particles in the wet air stream was significantly longer when particles were humidified in situ in the chamber. It took $\sim 1 \mathrm{~h}$ in the chamber, instead of $15 \mathrm{~s}$ in the $\mathrm{H}$ TDMA. These two approaches can thus be complementary to carry information on water transfer dynamics of $\alpha$-pinene$\mathrm{O}_{3}$ SOA. We used Mie scattering calculations for homogeneous spheres to determine GF from $f(\mathrm{RH}) . \sigma_{\text {scat }}$ was calculated for different GF at specific RH. The optimal GF as a function of RH was determined so that the difference between measured $\sigma_{\text {scat }}$ and those obtained using Mie calcula- 

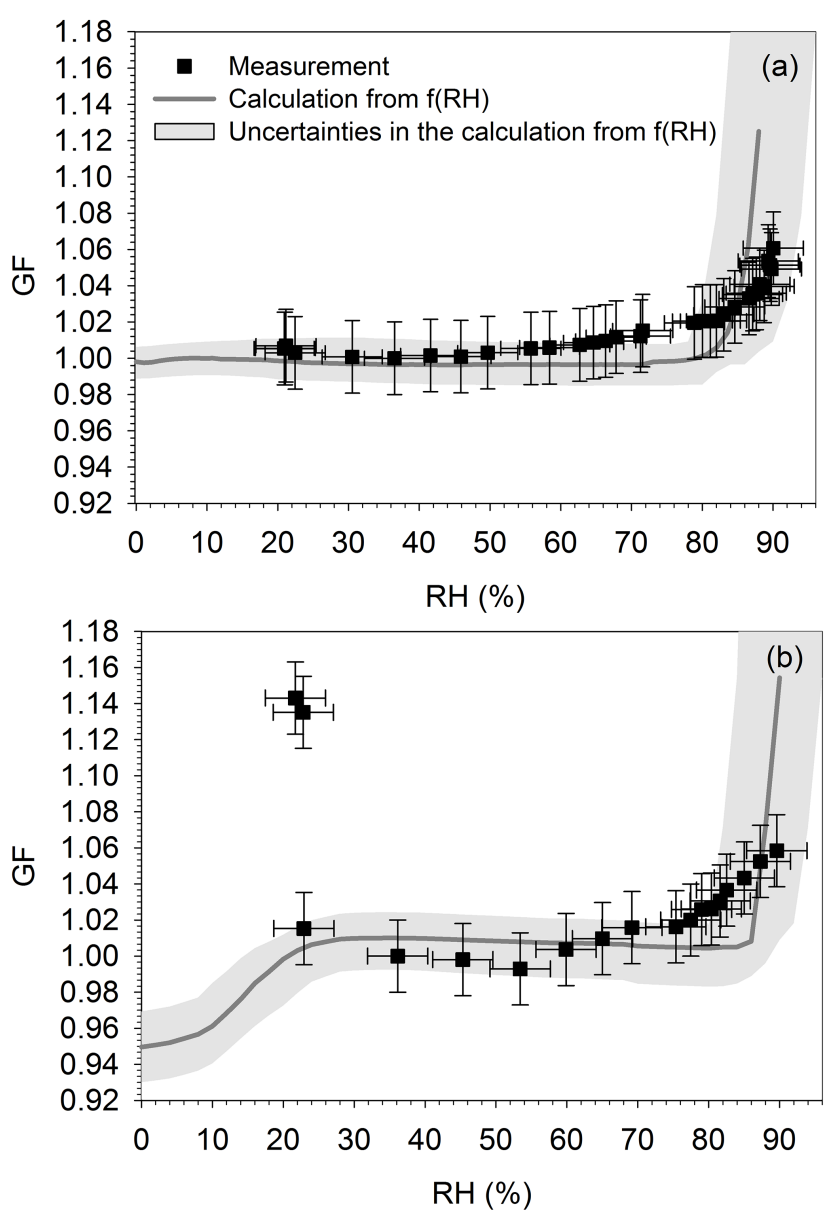

Figure 6. Humidograms showing measured (black symbols) and predicted GF (grey line) as a function of RH of SOA (a) after $1 \mathrm{~h}$ of reaction and (b) after $14 \mathrm{~h}$ of reaction. The grey area represent the uncertainties in the calculation of GF from $f(\mathrm{RH})$. For the calculations of GF, we used $D_{\mathrm{p}, \mathrm{m}}\left(\mathrm{RH}_{\mathrm{dry}}\right)$ at $40 \% \mathrm{RH}$.

tions were minimised. Particles were assumed to be homogeneous spheres of uniform CRI. The CRI calculations were based on volume-weighted refractive indices of SOA and water. Uncertainties on the theoretical GF were estimated from the standard deviation of the measured $f(\mathrm{RH})$, the uncertainties on the $f(\mathrm{RH})$ measurements and the uncertainties on the RH measurements. Figure 6 shows the comparison between measured and predicted GF values for SOA at two different reaction times: for fresh SOA (after $1 \mathrm{~h}$ of reaction), and for aged SOA (after $16 \mathrm{~h}$ of reaction). For both reaction times, the model approach agrees well with the measurements above $30 \% \mathrm{RH}$. It indicates no kinetic limitations of $\alpha$-pinene- $\mathrm{O}_{3}$ SOA for water uptake. For aged SOA (after $16 \mathrm{~h}$ of reaction), the underestimation of the model below $30 \%$ RH (Fig. 6) might be due to a change in the physical state of SOA, as discussed in detail in Sect. 4.2.

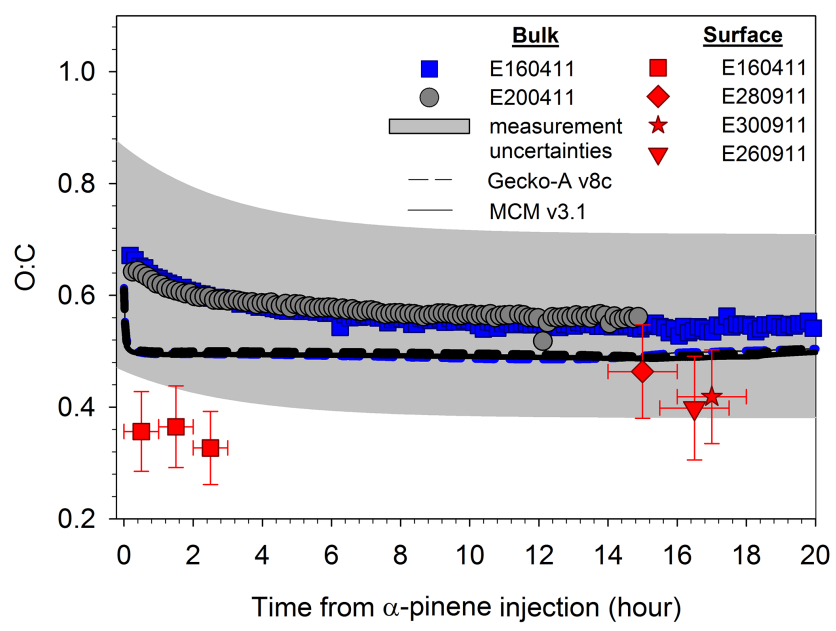

Figure 7. $\mathrm{O}: \mathrm{C}$ of the bulk SOA obtained from AMS measurements (blue and grey symbols) and uncertainties in the bulk $\mathrm{O}: \mathrm{C}$ values (grey area) as a function of time. These bulk O : C are compared with those of the SOA surface determined from XPS analysis (red symbols).

\subsection{Chemical composition}

The $\mathrm{O}: \mathrm{C}$ of the bulk aerosol measured online by the AMS and the $\mathrm{O}: \mathrm{C}$ at the surface obtained by XPS analysis on filter samples are shown in Fig. 7. The bulk $\mathrm{O}: \mathrm{C}$ ranged between $0.68( \pm 0.20)$ to $0.55( \pm 0.16)$. The uncertainties in bulk $\mathrm{O}: \mathrm{C}$ given by Aiken et al. (2007) may be overestimated compared to the experimental variability and even experimental reproducibility observed in this study. In fact, we estimated the experimental uncertainties to be \pm 0.01 from the standard deviation of the experimental values.

Two potential processes affecting the bulk $\mathrm{O}: \mathrm{C}$ during the SOA formation are the gas-/particle-phase partitioning and chemical reactions in the condensed phase. The evolution of the AMS mass spectra during the reaction is shown in Fig. S4 (Supplement). The AMS mass spectra were dominated by $m / z$ 44 for fresh SOA, while the strongest signal was observed at $m / z 29$ for aged SOA. Figure S5 also shows that $f_{44}$ decreased while $f_{43}$ increased with time. These observations indicate an increase of less oxidised semi-volatile compounds in the bulk particle phase with aging. This trend can be explained by an increasing partitioning of less oxidised semi-volatile compounds as the aerosol grows according to the structure-activity correlation between the oxygenated functional groups and the species vapour pressure (Pankow and Asher, 2008). Additionally, some oligomerisation/dehydration, such as aldol condensation or ester formation, can alter the SOA O : C and $f_{44}$ (Camredon et al., 2010; Ziemann and Atkinson, 2012). Additional reactions in the particle phase can take place after the SOA formation, and can for example lead to the formation of oligomers (Kalberer et al., 2004; Gao et al., 2004a, b; Tolocka et al., 2004; Yasmeen et al., 2012; Reinhardt et al., 2007; Rudich et al., 2007), 
Table 4. Comparison of bulk $\mathrm{O}: \mathrm{C}$ of $\alpha$-pinene- $\mathrm{O}_{3}$ SOA with previous studies in the literature.

\begin{tabular}{lll}
\hline Reference & Bulk O : C of SOA & Instrumentation \\
\hline This study & $0.55( \pm 0.16)-0.68( \pm 0.20)$ & HR-ToF-AMS \\
Aiken et al. (2007) & $0.27( \pm 0.08)$ & HR-ToF-AMS \\
Shilling et al. (2008) & $0.29( \pm 0.09)-0.45( \pm 0.14)$ & HR-ToF-AMS \\
Chhabra et al. (2010) & $0.43( \pm 0.13)$ & HR-ToF-AMS \\
Qi et al. (2012) & 0.33 & HR-ToF-AMS \\
Reinhardt et al. (2007) & $0.4-0.6$ & FTICR-MS \\
Tolocka et al. (2006) & $0.37( \pm 0.05)-0.40( \pm 0.12)$ & NanoAMS \\
\hline
\end{tabular}

but do not appear to be associated with a significant change in the SOA functionality.

Bulk $\mathrm{O}: \mathrm{C}$ obtained in the literature from different techniques are shown in Table 4. The bulk $\mathrm{O}: \mathrm{C}$ retrieved in our study are in agreement with Shilling et al. (2008), Chhabra et al. (2010), Reinhardt et al. (2007) and Tolocka et al. (2006). Values at the beginning of the reaction are, however, higher than those obtained by Aiken et al. (2007) and Qi et al. (2012) who used AMS to retrieve the $\mathrm{O}: \mathrm{C}$. Limited information is given by Aiken et al. (2007) about their experimental conditions. In particular, temperature and reaction timescales are critical parameters which can significantly affect the chemical composition of SOA (Warren et al., 2009; Shilling et al., 2008; Chhabra et al., 2010). Qi et al. (2012) did not provide any uncertainty in their AMS measurements, but taking into account the uncertainties of $\pm 30 \%$ given by Aiken et al. (2007), their O : Cs are in agreement with our values.

The $\mathrm{O}: \mathrm{C}$ at the surface of the SOA is significantly lower than in the bulk (Fig. 7) and ranged between $0.33( \pm 0.07)$ and $0.46( \pm 0.08)$. Some volatile compounds could evaporate during the XPS analysis due to the low pressure in the instrument. In our companion paper (Denjean et al., 2015), an increase of the $\mathrm{O}: \mathrm{C}$ has been observed after heating by the evaporation of semi-volatile components of SOA. Therefore, the $\mathrm{O}: \mathrm{C}$ at the surface of the SOA was certainly overestimated in the present study. This suggests that the SOA composition is not homogeneous, but composed of less oxidised species at its surface. To our knowledge, our study is the first one to investigate the surface $\mathrm{O}: \mathrm{C}$ of the SOA and thus no comparison with literature is possible. Nevertheless, this observation is in very good agreement with one of the hypotheses by McIntire et al. (2010). The authors proposed a hydrophobic shell model for hydrocarbon $+\mathrm{O}_{3}$ SOA due to the burying of $\mathrm{R}-\mathrm{COOH}$ compounds and other polar groups inside the particle. Here, we report direct experimental measurements which support this hypothesis.

We examined the sensitivity of the SOA chemical composition on the surface $\mathrm{O}: \mathrm{C}$ by calculating the $\mathrm{O}: \mathrm{C}$ of the core. For simplicity, we assumed that the $\mathrm{O}: \mathrm{C}$ of the core SOA is constant and independent on the distance from the centre of the particle. $\mathrm{O}: \mathrm{C}$ of the core can be expressed as a function of the $\mathrm{O}: \mathrm{C}$ of the bulk from AMS measurements, the $\mathrm{O}: \mathrm{C}$ at the surface from XPS and the mass fraction of surface and

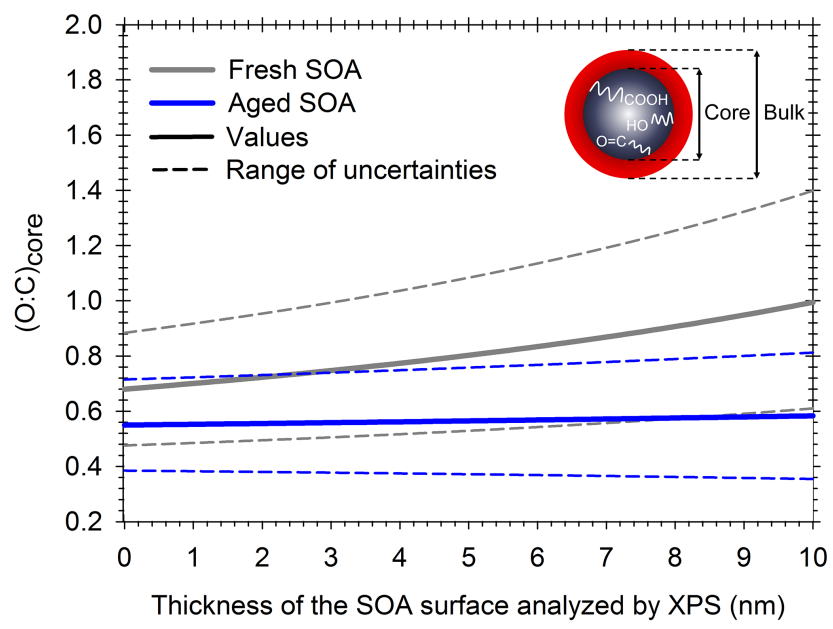

Figure 8. Effect of the thickness of the SOA surface on the core $\mathrm{O}: \mathrm{C}$ ratio. Values are calculated for SOA after $1 \mathrm{~h}$ of reaction (grey) and after $14 \mathrm{~h}$ of reaction and aged SOA (blue).

core in the particle:

$(\mathrm{O}: \mathrm{C})_{\text {core }}=\frac{(\mathrm{O}: \mathrm{C})_{\text {bulk }}-\frac{\mathrm{m}_{\text {surf }}}{\mathrm{m}_{\text {bulk }}}(\mathrm{O}: \mathrm{C})_{\text {surf }}}{\frac{\mathrm{m}_{\text {core }}}{\mathrm{m}_{\text {bulk }}}}$.

XPS quantifies the $\mathrm{O}: \mathrm{C}$ of the SOA surface to a depth less than $10 \mathrm{~nm}$. However, this technique cannot provide the precise thickness of the surface analysed and it is possible that the $\mathrm{O}: \mathrm{C}$ corresponds to a thinner layer. Therefore, $\mathrm{O}: \mathrm{C}$ of the core SOA was calculated for different possible thicknesses of the analysed surface $\mathrm{O}: \mathrm{C}$. Figure 8 shows the $\mathrm{O}: \mathrm{C}$ of the core for fresh and aged SOA. From these calculations, we observed that bulk $\mathrm{O}: \mathrm{C}$ ranges from $0.68( \pm 0.20)$ to $1.01( \pm 0.40)$ for fresh SOA and from $0.55( \pm 0.17)$ to 0.58 $( \pm 0.23)$ for aged SOA. Based on the elemental composition of identified compounds of $\alpha$-pinene- $\mathrm{O}_{3}$ SOA, highly oxygenated compounds were found in the literature. For example, peroxypinic acid is a product of $\alpha$-pinene ozonolysis proposed by Docherty et al. (2005) with $\mathrm{O}: \mathrm{C}=0.56$. This simple calculation highlights the importance of monitoring the surface chemical composition separately from the bulk.

\section{Discussion}

\subsection{Dependence of the CRI and GF on the chemical composition}

Our results suggest that the real part of the CRI is closely related to SOA chemical composition. Figure 9 shows that the real part of the CRI decreases substantially as the O:C of the bulk SOA decreases. This trend is in agreement with the positive correlation between the extinction coefficient at $532 \mathrm{~nm}$ wavelength and O : C observed by Cappa et al. (2011) for the heterogeneous $\mathrm{OH}$ oxidation of squalane and aze- 

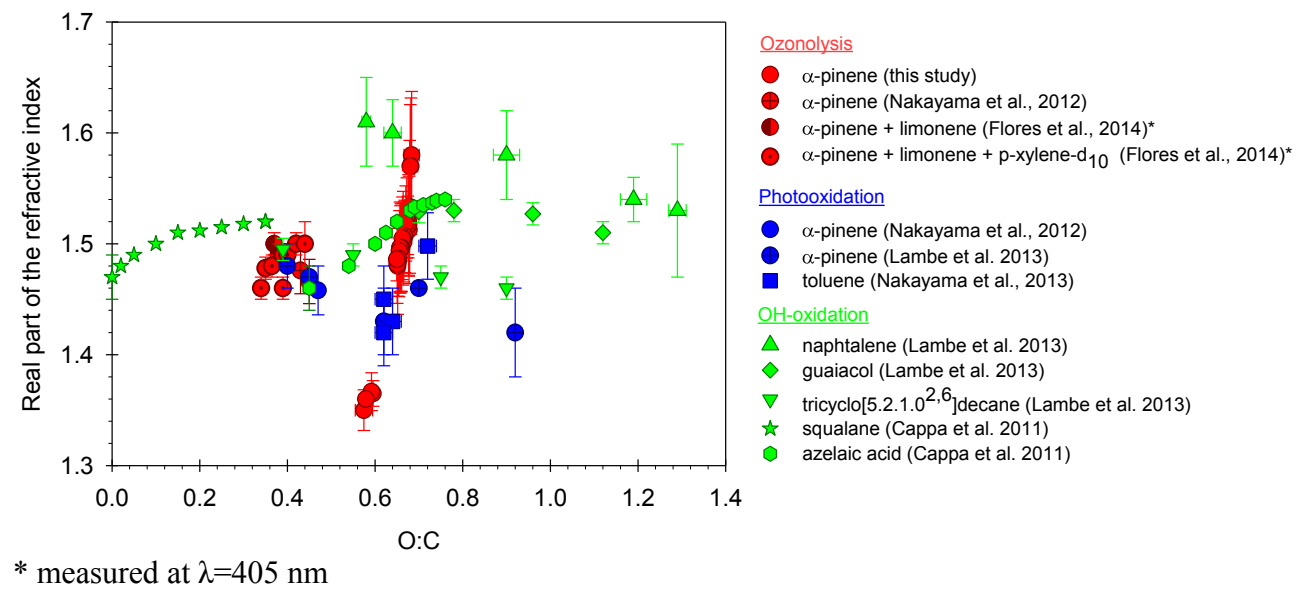

Figure 9. Real part of the refractive indices at $\lambda=525 \mathrm{~nm}$ of SOA as a function of the bulk O:C. In our study, representative error bars represent $\pm 1 \sigma$ in replicate measurement.

laic acid particles. Nakayama et al. (2013) reported an increasing real part of the CRI at $532 \mathrm{~nm}$ with increasing O : C for SOA generated from the photooxidation of toluene. Recently, Flores et al. (2014) showed that the real part of the $\mathrm{CRI}$ at $405 \mathrm{~nm}$ is positively correlated to the $\mathrm{O}: \mathrm{C}$ for a mixture of biogenic VOC ( $\alpha$-pinene and limonene) and biogenic VOC mixture with subsequent addition of an anthropogenic VOC ( $p$-xylene- $\left.\mathrm{d}_{10}\right)$. On the other hand, an opposite trend was observed by Nakayama et al. (2012) with a decrease of the real part of the CRI at $532 \mathrm{~nm}$ wavelength with increasing $\mathrm{O}: \mathrm{C}$ for SOA produced from the ozonolysis and photooxidation of $\alpha$-pinene. Lambe et al. (2013) studied SOA formed by $\mathrm{OH}$ oxidation of various gas-phase precursors (naphthalene, tricyclo[5.2.1. $\left.0^{2,6}\right]$ decane, guaiacol and $\alpha$-pinene) and retrieved a decreasing real part of the CRI with increasing oxidation. These different trends suggest that the change of the real CRI as a function of $\mathrm{O}: \mathrm{C}$ depends strongly on the organic aerosol source and aging in the atmosphere.

The decrease of bulk $\mathrm{O}: \mathrm{C}$ is expected to induce a decrease in SOA hygroscopic properties (Massoli et al., 2010; Jimenez et al., 2009; Chang et al., 2010; Duplissy et al., 2011). However, the GF remained surprisingly constant over $20 \mathrm{~h}$ of reaction (Fig. 4). This trend contradicts Saathoff et al. (2003) and Cocker et al. (2001) who reported an increase of the GF from 1.080 to 1.106 and 1.065 to 1.1 , respectively, within timescale of $6 \mathrm{~h}$. However, our constant GF is consistent with the constant hygroscopicity observed by Warren et al. (2009) and Qi (2010) for $\alpha$-pinene- $\mathrm{O}_{3}$ SOA. The constant GF observed in our study may result from (1) the sensitivity of the instruments. The GF was studied after $2 \mathrm{~h}$ of reaction when the decrease of the oxidation degree was slow. The O:C of bulk SOA decreased from 0.65 to 0.60 between 2 and $10 \mathrm{~h}$ of aging (Fig. 7), that should result in a GF decrease of 0.03 according to the linear GF-to-O : C relationship reported by Massoli et al. (2010). This expected GF variation (due to the chemical composition change) is smaller than the sensitivity of the H-TDMA. (2) Other factors, other than the bulk $\mathrm{O}: \mathrm{C}$, can control the water uptake of SOA. Recently, Alfarra et al. (2014) reported a positive correlation between hygroscopicity of particles and their degree of oxidation for SOA produced from the photooxidation of $\alpha$-pinene, $\beta$-caryophyllene, linalool and myrcene, but not for limonene SOA. They suggested that other factors such as solubility, surface tension, molecular weight, density and particle phase are likely to be playing important roles in controlling GF values. We observed that the $\mathrm{O}: \mathrm{C}$ of the particle surface was lower than the bulk $\mathrm{O}: \mathrm{C}$ and remained constant over time (see Sect. 3.4.1). This structure would affect the heterogeneous chemistry of the particle and avoid the water absorption on particles. Broekhuizen et al. (2004) observed that the oxidation of oleic acid by low concentration of ozone, shown to produce oxygenated products (Moise and Rudich, 2002), did not increase the particle CCN activity. Katrib et al. (2004) demonstrated that hydrophobic products were formed at the surface of oleic acid particles after ozone exposure that prevented water adsorption on particles. McIntire et al. (2010) exposed particles formed from ozonolysis of surface-bound alkenes to ozone and observed formation of polar groups buried inside a hydrophobic shell. This is also consistent with Moussa et al. (2009) who observed that the uptake of water does not increase after the oxidation of surface-bound alkenes. A core-shell structure could explain the low $\mathrm{O}: \mathrm{C}$ of the surface $\alpha$-pinene- $\mathrm{O}_{3}$ SOA obtained in the present study and could significantly affect the heterogeneous chemistry of the particle.

\subsection{Effect of RH and aging on the viscosity of SOA}

An unexpected effect of aging on the dynamic of the size distribution evolution during humidification has been observed (Sect. 3.3 and Fig. 5). For the $16 \mathrm{~h}$ old SOA, humidification led to a decay of the mobility diameter and an increase of 
$\sigma_{\text {scatt }}$ while such behaviour was not observed for the $1 \mathrm{~h}$ old reaction. Although evaporation of semi-volatiles in the chamber could lead to a decrease of the observed mobility diameter, it cannot explain the increase of $f(\mathrm{RH})$ below $40 \% \mathrm{RH}$. Furthermore, the observed decrease of the mobility diameter cannot be attributed to losses of particles to the walls of the chamber, since it would lead to a decrease of $f(\mathrm{RH})$.

As it is difficult to believe that a RH increase would induce a sudden loss of matter for the particulate phase, it is hypothesised that the particles experienced a rapid change of shape when humidified. Being observed for aged SOA only, these behaviours support a re-shaping of coagulated particles and an increase in sphericity for RH $>20-30 \%$. This implies that, below these RH values, coagulated particles were not spherical and hence they were not liquid enough for coalescence. Electron microscopy analysis was used to investigate the shape of SOA particles. SOA particles after $1 \mathrm{~h}$ and $14 \mathrm{~h}$ of reaction were analysed by transmission electron microscopy (TEM) (Fig. S6 in the Supplement). Experimental details are given in the Supplement. In total 50 particles were analysed by TEM. Figure S6 shows an example of SOA particles after 1 and $14 \mathrm{~h}$ of reaction. Only spherical particles have been observed in the samples. This indicates that the coagulation taking place at the beginning and after $14 \mathrm{~h}$ of reaction resulted in spherical coalesced particles.

A few recent studies have suggested that $\alpha$-pinene- $\mathrm{O}_{3}$ SOA is likely to be in an amorphous semi-solid or in an amorphous solid (glassy) state under dry conditions $(\mathrm{RH}<30 \%)$. Virtanen et al. (2011) reported that $\alpha$-pinene- $\mathrm{O}_{3}$ SOA bounces off impactor plates as if particles were glassy. Other studies reported that the evaporation kinetics of $\alpha$-pinene- $\mathrm{O}_{3}$ SOA was lower than expected by models for liquid droplets, indicating a non-liquid-like state (Cappa and Wilson, 2011; Vaden et al., 2011). These findings are in agreement with Perraud et al. (2012) who has shown that the uptake of organic nitrates by $\alpha$-pinene- $\mathrm{O}_{3}$ SOA did not follow absorptive equilibrium partitioning theory, as indicative of non-liquidlike behaviour. Moreover, some recent studies reported viscosity changes of $\alpha$-pinene- $\mathrm{O}_{3}$ SOA with $\mathrm{RH}$. Saukko et al. (2012) observed lower bounce behaviour after the SOA was exposed to $\mathrm{RH}>50 \%$, indicating a liquid-like, less viscous phase. Renbaum-Wolff et al. (2013) reported that the viscosities of $\alpha$-pinene- $\mathrm{O}_{3}$ SOA correspond to a semi-solid or solid for $\mathrm{RH} \leq 30 \%$, a semi-solid for $40 \% \leq \mathrm{RH}<80 \%$ and a liquid for $\mathrm{RH} \geq 80 \%$. This is consistent with our observation of the apparent step in mobility diameter and $\sigma_{\text {scatt }}$ changes observed between 0 and $30 \%$ RH for SOA after $16 \mathrm{~h}$ of reaction (Fig. 5), which may be due to phase transition from a predominantly glassy state to a predominantly liquid state.

In addition, we find no apparent transition step between 0 and $30 \% \mathrm{RH}$ for SOA after $1 \mathrm{~h}$ of reaction. This observation mirrors the effect of aging on the physical state of SOA. We discussed previously the possible formation of oligomers in the particle phase during the formation of SOA. Roth et al. (2005) suggested that ambient organic particles could be in an extremely high viscosity, glassy state due to the presence of oligomeric constituents. There is evidence from different organic materials that oligomerisation may lead to an increase in viscosity and potentially to the formation of glassy states (Koop et al., 2011). Abramson et al. (2013) reported decreasing evaporation kinetics during the aging of $\alpha$ pinene- $\mathrm{O}_{3}$ SOA, indicating that hardening occurs with time. Our observations are consistent with an increase in the SOA oligomer content with aging, leading to the transformation of SOA into glassy states under dry conditions.

These findings are of major importance as it suggests that particles may undergo reorganisation after the condensation of oxidised species. It is also supported by the core-shell structure of SOA observed with less oxidised species at its surface (Sect. 3.4.1. and Fig. 7). Due to possible kinetic limitations, the particles viscosity can strongly affect a number of key physical and chemical properties, such as water uptake, equilibrium partitioning between the gas and the particle phase or heterogeneous chemistry (Koop et al., 2011; Zobrist et al., 2008, Milkhailov et al., 2009, Murray 2008; Shiraiwa et al., 2013) and thus has considerable implications on the understanding of the impact of SOA on climate.

\subsection{Implication for direct radiative effect and conclusions}

The imaginary part of the CRI values for $\alpha$-pinene- $\mathrm{O}_{3}$ SOA was found to be negligible in the visible spectrum, indicating that these particles have a pure scattering effect. The single scattering albedo $\omega_{0}$, a key parameter to estimate the influence of aerosols on the radiative balance, is estimated to be equal to 1 , indicating that these particles have a negative radiative effect.

In order to estimate the evolution of the direct radiative effect of SOA, the mass extinction efficiency $k_{\text {ext }}$ (dry) at $525 \mathrm{~nm}$ of dry SOA is shown in Fig. 10 . The $k_{\text {ext }}$ values were calculated as the ratio of the measured SOA $\sigma_{\text {scat }}$ to their mass concentration. The $k_{\text {ext }}$ values depend on the competitive effect of aerosol size and chemical composition. The decrease of the real CRI resulting from the changing particle chemical composition is expected to decrease $k_{\text {ext }}$, while the size increase of the SOA from the nucleation mode to the accumulation mode should increase $k_{\text {ext }}$. At the beginning of the SOA formation, we obtained $k_{\text {ext }}$ (dry) $=0.64 \pm 0.27 \mathrm{~m}^{-2} \mathrm{~g}^{-1}$ that is significantly lower than that obtained after $14 \mathrm{~h}$ of reaction where $k_{\mathrm{ext}}$ $($ dry $)=1.68 \pm 0.50 \mathrm{~m}^{-2} \mathrm{~g}^{-1}$. The mass extinction efficiency $k_{\text {ext }}$ is also strongly affected by the ambient relative humidity (Fig. 10). $\alpha$-Pinene-O $\mathrm{O}_{3}$ SOA did not show deliquescence below $90 \% \mathrm{RH}$, but a continuous water uptake with increasing RH. A constant GF (90\% RH) was obtained throughout the experiment. From the measured $f(90 \% \mathrm{RH})$ and $\mathrm{GF}(90 \% \mathrm{RH})$ obtained in this study, we can estimate $\sigma_{\text {scat }}$ and SOA mass concentration at $90 \% \mathrm{RH}$ and then $k_{\mathrm{ext}}(90 \%$ 


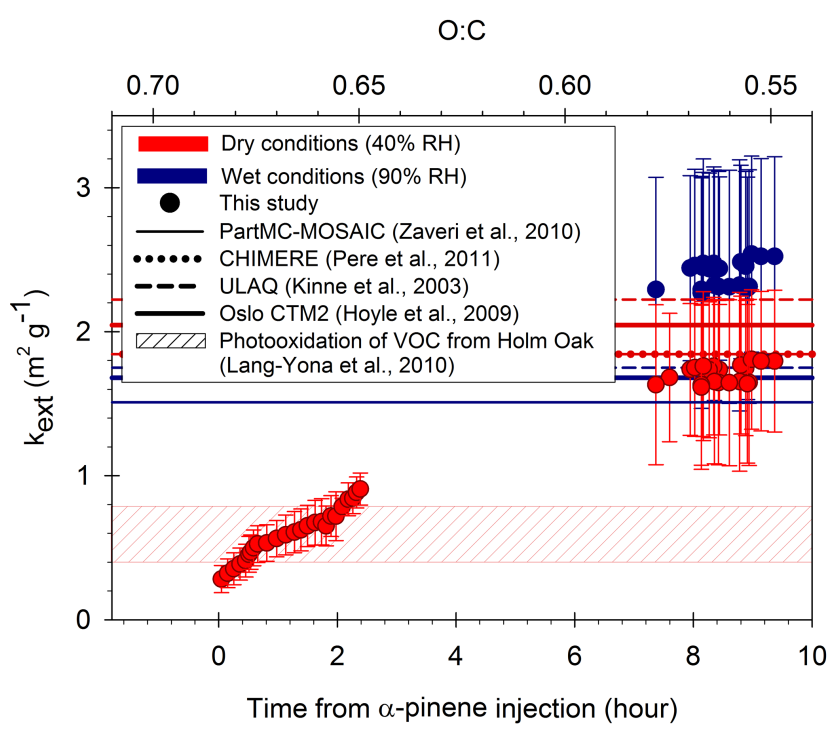

Figure 10. Mass extinction efficiency $\left(k_{\text {ext }}\right)$ at $\lambda=525 \mathrm{~nm}$ of SOA under dry (red dots) and wet conditions (blue dots) as a function of time and bulk $\mathrm{O}: \mathrm{C}$. These $k_{\text {ext }}$ values are compared to those used for organic aerosols in several global models (lines) and those of SOA generated from a mixture of biogenics released directly from plants (dashed area). Zaveri et al. (2010) assumed a CRI of 1.45-0i and GF of 1.23, Pere et al. (2011) a CRI of 1.45-0.001i, Kinne et al. (2003) a CRI of 1.60-0.003i and GF of 1.09 (for ULAQ model) and Hoyle et al. (2009) a CRI of 1.53-0i and GF of 1.03. The hygroscopic growth of SOA was not taken into account by Pere et al. (2011).

$\mathrm{RH})=2.36 \pm 0.70 \mathrm{~m}^{-2} \mathrm{~g}^{-1}$. Water uptake by SOA at $90 \%$ RH produces an increase of $k_{\text {ext }}$ by $40 \%$. This simple calculation highlights the importance of taking into account the actual ambient conditions that the $\alpha$-pinene- $\mathrm{O}_{3}$ SOA experiences during its lifetime when estimating its induced direct radiative effect in the atmosphere.

For comparison, $k_{\text {ext }}$ of organic aerosols calculated using the CRI and GF as prescribed in global models are shown in Fig. 10. Mie scattering calculations for homogeneous spheres were performed to calculate $k_{\text {ext }}$. Number size distribution representing biogenic aerosol particles in the Amazon Basin (Martin et al., 2010) was used as an input in the Mie scattering calculations. For wet conditions, the CRI calculations were based on volume-weighted CRI of values of $\alpha$-pinene$\mathrm{O}_{3}$ SOA and water. $k_{\text {ext }}$ of SOA generated from a mixture of biogenics (mostly terpenes) released directly from plants (Lang-Yona et al, 2010) is also shown in Fig. 10. Despite the wide range of variability of the CRI values assumed in global models for organic aerosols (1.45-0i to 1.6-0.003i), the values for $k_{\text {ext }}$ were very similar for all models. The $k_{\text {ext }}$ values retrieved in the present study for SOA after $14 \mathrm{~h}$ of reaction agree with the values used for global models, while $k_{\text {ext }} \mathrm{ob}-$ tained for SOA at the beginning of the reaction are 2-7 times smaller. This work is a first attempt to assess the evolution of $k_{\text {ext }}$ of SOA during its formation and aging. Our results suggest that the $k_{\text {ext }}$ of atmospheric SOA is not static and a single size distribution and CRI does not appear sufficient to accurately model its direct radiative effect.

\section{The Supplement related to this article is available online at doi:10.5194/acp-15-3339-2015-supplement.}

Acknowledgements. This research work has been supported by the European Community within the seventh Framework Programme: Eurochamp-2 (EU-FP7 grant agreement no. 228335). We also acknowledge the National Research Agency ANR (project CUMULUS, no. ANR-10-BLAN-0617). We thank Frank Siekmann and Sylvain Ravier (Aix-Marseille Université, France) for their help in calibrating the AMS during the measurement campaign. We thank Michel Maille (LISA, France) for the analysis with electron microscopy. We gratefully acknowledge the MASSALYA instrumental platform (Aix Marseille Université, lce.univ-amu.fr) for the analysis and measurements used in this publication. We thank Brendan Mahon and Steven J. Campbell (University of Cambridge, UK) for helpful revision of the manuscript.

Edited by: A. Virtanen

\section{References}

Abramson, E., Imre, D., Beranek, J., Wilson, J., and Zelenyuk, A.: Experimental determination of chemical diffusion within secondary organic aerosol particles, Phys. Chem. Chem. Phys., 15, 2983-2991, doi:10.1039/C2CP44013J, 2013.

Adachi, K., Freney, E. J., and Buseck, P. R.: Shapes of internally mixed hygroscopic aerosol particles after deliquescence, and their effect on light scattering, Geophys. Res. Lett., 38, L13804, doi:10.1029/2011GL047540, 2011.

Aiken, A. C., DeCarlo, P. F., and Jimenez, J. L.: Elemental analysis of organic species with electron ionization high-resolution mass spectrometry, Anal. Chem., 79, 8350-8358, 2007.

Aiken, A. C., DeCarlo, P. F., Kroll, J. H., Worsnop, D. R., Huffman, J. A., Docherty, K. S., Ulbrich, I. M., Mohr, C., Kimmel, J. R., Sueper, D., Sun, Y., Zhang, Q., Trimborn, A., Northway, M., Ziemann, P. J., Canagaratna, M. R., Onasch, T. B., Alfarra, M. R., Prevot, A. S. H., Dommen, J., Duplissy, J., Metzger, A., Baltensperger, U., and Jimenez, J. L.: O/C and OM/OC ratios of primary, secondary, and ambient organic aerosols with high-resolution time-of-flight aerosol mass spectrometry, Environ. Sci. Technol., 42, 4478-4485, doi:10.1021/es703009q, 2008.

Allan, J. D., Delia, A. E., Coe, H., Bower, K. N., Alfarra, M. R., Jimenez, J. L., Middlebrook, A. M., Drewnick, F., Onasch, T. B., Canagaratna, M. R., Jayne, J. T., and Worsnop, D. R.: A generalised method for the extraction of chemically resolved mass spectra from aerodyne aerosol mass spectrometer data, J. Aerosol Sci., 35, 909-922, doi:10.1016/j.jaerosci.2004.02.007, 2004. 
Andreae, M. O.: A new look at aging aerosols, Science, 326, 14931494, doi:10.1126/science.1183158, 2009.

Arnott, W. P., Hamasha, K., Moosmuller, H., Sheridan, P. J., and Ogren, J. A.: Towards aerosol light-absorption measurements with a 7-wavelength Aethalometer: evaluation with a photoacoustic instrument and 3-wavelength nephelometer, Aerosol Sci. Tech., 39, 17-29, doi:10.1080/027868290901972, 2005.

Baltensperger, U.: Secondary organic aerosols from anthropogenic and biogenic precursors, Roy. Soc. Ch., 130, 265-278, 2005.

Biskos, G., Russell, L. M., Buseck, P. R., and Martin, S. T.: Nanosize effect on the hygroscopic growth factor of aerosol particles, Geophys. Res. Lett., 33, L07801, doi:10.1029/2005GL025199, 2006.

Bohren, C. F. and Huffman, D. R.: Absorption and Scattering of Light by Small Particles, Wiley, New York, 1983.

Bond, T. C. and Bergstrom, R. W.: Light absorption by carbonaceous particles: an investigative review, Aerosol Sci. Tech., 40, 27-67, doi:10.1080/02786820500421521, 2006.

Bond, T. C., Anderson, T. L., and Campbell, D.: Calibration and intercomparison of filter-based measurements of visible light absorption by aerosols, Aerosol Sci. Tech., 30, 582-600, doi:10.1080/027868299304435, 1999.

Broekhuizen, K. E., Thornberry, T., Kumar, P. P., and Abbatt, J. P. D.: Formation of cloud condensation nuclei by oxidative processing: Unsaturated fatty acids, J. Geophys. Res.-Atmos., 109, D24206, doi:10.1029/2004JD005298, 2004.

Camredon, M., Hamilton, J. F., Alam, M. S., Wyche, K. P., Carr, T., White, I. R., Monks, P. S., Rickard, A. R., and Bloss, W. J.: Distribution of gaseous and particulate organic composition during dark $\alpha$-pinene ozonolysis, Atmos. Chem. Phys., 10, 2893-2917, doi:10.5194/acp-10-2893-2010, 2010.

Canagaratna, M. R., Jayne, J. T., Jimenez, J. L., Allan, J. D., Alfarra, M. R., Zhang, Q., Onasch, T. B., Drewnick, F., Coe, H., Middlebrook, A., Delia, A., Williams, L. R., Trimborn, A. M., Northway, M. J., DeCarlo, P. F., Kolb, C. E., Davidovits, P., and Worsnop, D. R.: Chemical and microphysical characterization of ambient aerosols with the aerodyne aerosol mass spectrometer, Mass Spectrom. Rev., 26, 185-222, doi:10.1002/mas.20115, 2007.

Cappa, C. D. and Wilson, K. R.: Evolution of organic aerosol mass spectra upon heating: implications for OA phase and partitioning behavior, Atmos. Chem. Phys., 11, 1895-1911, doi:10.5194/acp11-1895-2011, 2011.

Cappa, C. D., Lack, D. A., Burkholder, J. B., and Ravishankara, A. R.: Bias in filter-based aerosol light absorption measurements due to organic aerosol loading: evidence from laboratory measurements, Aerosol Sci. Tech., 42, 1022-1032, 2008.

Cappa, C. D., Che, D. L., Kessler, S. H., Kroll, J. H., and Wilson, K. R.: Variations in organic aerosol optical and hygroscopic properties upon heterogeneous OH oxidation, J. Geophys. Res., 116, D15204, doi:10.1029/2011JD015918, 2011.

Carrico, C. M., Kreidenweis, S. M., Malm, W. C., Day, D. E., Lee, T., Carrillo, J., McMeeking, G. R., and Collett Jr., J. L.: Hygroscopic growth behavior of a carbon-dominated aerosol in Yosemite National Park, Atmos. Environ., 39, 1393-1404, 2005.

Chan, M. N. and Chan, C. K.: Mass transfer effects in hygroscopic measurements of aerosol particles, Atmos. Chem. Phys., 5, 2703-2712, doi:10.5194/acp-5-2703-2005, 2005.
Chan, A. W. H., Kroll, J. H., Ng, N. L., and Seinfeld, J. H.: Kinetic modeling of secondary organic aerosol formation: effects of particle- and gas-phase reactions of semivolatile products, Atmos. Chem. Phys., 7, 4135-4147, doi:10.5194/acp-7-4135-2007, 2007.

Chang, R. Y.-W., Slowik, J. G., Shantz, N. C., Vlasenko, A., Liggio, J., Sjostedt, S. J., Leaitch, W. R., and Abbatt, J. P. D.: The hygroscopicity parameter $(\kappa)$ of ambient organic aerosol at a field site subject to biogenic and anthropogenic influences: relationship to degree of aerosol oxidation, Atmos. Chem. Phys., 10, 5047-5064, doi:10.5194/acp-10-5047-2010, 2010.

Charlson, R. J., Schwartz, S. E., Hales, J. M., Cess, R. D., Coakley, J. A., Hansen, J. E., and Hofmann, D. J.: Climate forcing by anthropogenic aerosols, Science, 255, 423-430, doi:10.1126/science.255.5043.423, 1992.

Chen, Q., Liu, Y. J., Donahue, N. M., Shilling, J. E., and Martin, S. T.: Particle-phase chemistry of secondary organic material: modeled compared to measured $\mathrm{O}: \mathrm{C}$ and $\mathrm{H}: \mathrm{C}$ elemental ratios provide constraints, Environ. Sci. Technol., 45, 4763-4770, doi:10.1021/es104398s, 2011.

Chhabra, P. S., Flagan, R. C., and Seinfeld, J. H.: Elemental analysis of chamber organic aerosol using an aerodyne high-resolution aerosol mass spectrometer, Atmos. Chem. Phys., 10, 4111-4131, doi:10.5194/acp-10-4111-2010, 2010.

Chung, S. H. and Seinfeld, J. H.: Global distribution and climate forcing of carbonaceous aerosols, J. Geophys. Res., 107, 4407, doi:10.1029/2001JD001397, 2002.

Cocker, D. R., Mader, B. T., Kalberer, M., Flagan, R. C., and Seinfeld, J. H.: The effect of water on gas-particle partitioning of secondary organic aerosol: II. M-xylene and 1,3,5trimethylbenzene photooxidation systems, Atmos. Environ., 35, 6073-6085, doi:10.1016/s1352-2310(01)00405-8, 2001.

Collaud Coen, M., Weingartner, E., Apituley, A., Ceburnis, D., Fierz-Schmidhauser, R., Flentje, H., Henzing, J. S., Jennings, S. G., Moerman, M., Petzold, A., Schmid, O., and Baltensperger, U.: Minimizing light absorption measurement artifacts of the Aethalometer: evaluation of five correction algorithms, Atmos. Meas. Tech., 3, 457-474, doi:10.5194/amt-3457-2010, 2010.

DeCarlo, P. F., Kimmel, J. R., Trimborn, A., Northway, M. J., Jayne, J. T., Aiken, A. C., Gonin, M., Fuhrer, K., Horvath, T., Docherty, K. S., Worsnop, D. R., and Jimenez, J. L.: Fielddeployable, high-resolution, time-of-flight aerosol mass spectrometer, Anal. Chem., 78, 8281-8289, doi:10.1021/ac061249n, 2006.

de Gouw, J. A., Middlebrook, A. M., Warneke, C., Goldan, P. D., Kuster, W. C., Roberts, J. M., Fehsenfeld, F. C., Worsnop, D. R., Canagaratna, M. R., Pszenny, A. A. P., Keene, W. C., Marchewka, M., Bertman, S. B., and Bates, T. S.: Budget of organic carbon in a polluted atmosphere: results from the New England Air Quality Study in 2002, J. Geophys. Res.-Atmos., 110, D16305, doi:10.1029/2004jd005623, 2005.

Denjean, C., Formenti, P., Picquet-Varrault, B., Katrib, Y., Pangui, E., Zapf, P., and Doussin, J. F.: A new experimental approach to study the hygroscopic and optical properties of aerosols: application to ammonium sulfate particles, Atmos. Meas. Tech., 7, 183-197, doi:10.5194/amt-7-183-2014, 2014.

Denjean, C., Formenti, P., Picquet-Varrault, B., Camredon, M., Pangui, E., Zapf, P., Katrib, Y., Giorio, C., Tapparo, A., Temime- 
Roussel, B., Monod, A., Aumont, B., and Doussin, J. F.: Aging of secondary organic aerosol generated from the ozonolysis of $\alpha$-pinene: effects of ozone, light and temperature, Atmos. Chem. Phys., 15, 883-897, doi:10.5194/acp-15-883-2015, 2015.

Dinar, E., Riziq, A. A., Spindler, C., Erlick, C., Kiss, G., and Rudich, Y.: The complex refractive index of atmospheric and model humic-like substances (HULIS) retrieved by a cavity ring down aerosol spectrometer (CRD-AS), Faraday Discuss., 137, 279-295, doi:10.1039/b703111d, 2008.

Docherty, K. S., Wu, W., Lim, Y. B., and Ziemann, P. J.: Contributions of organic peroxides to secondary aerosol formed from reactions of monoterpenes with $\mathrm{O}_{3}$, Environ. Sci. Technol., 39, 4049-4059, doi:10.1021/es050228s, 2005.

Donahue, N. M., Henry, K. M., Mentel, T. F., Kiendler-Scharr, A., Spindler, C., Bohn, B., Brauers, T., Dorn, H. P., Fuchs, H., Tillmann, R., Wahner, A., Saathoff, H., Naumann, K. H., Mohler, O., Leisner, T., Muller, L., Reinnig, M. C., Hoffmann, T., Salo, K., Hallquist, M., Frosch, M., Bilde, M., Tritscher, T., Barmet, P., Praplan, A. P., DeCarlo, P. F., Dommen, J., Prevot, A. S. H., and Baltensperger, U.: Aging of biogenic secondary organic aerosol via gas-phase $\mathrm{OH}$ radical reactions, P. Natl. Acad. Sci. USA, 109, 13503-13508, doi:10.1073/pnas.1115186109, 2012.

Duplissy, J., DeCarlo, P. F., Dommen, J., Alfarra, M. R., Metzger, A., Barmpadimos, I., Prevot, A. S. H., Weingartner, E., Tritscher, T., Gysel, M., Aiken, A. C., Jimenez, J. L., Canagaratna, M. R., Worsnop, D. R., Collins, D. R., Tomlinson, J., and Baltensperger, U.: Relating hygroscopicity and composition of organic aerosol particulate matter, Atmos. Chem. Phys., 11, 1155-1165, doi:10.5194/acp-11-1155-2011, 2011.

Dusek, U., Reischl, G. P., and Hitzenberger, R.: CCN activation of pure and coated carbon black particles, Environ. Sci. Technol., 40, 1223-1230, 2006.

Flores, J. M., Zhao, D. F., Segev, L., Schlag, P., Kiendler-Scharr, A., Fuchs, H., Watne, A. K., Bluvshtein, N., Mentel, Th. F., Hallquist, M., and Rudich, Y.: Evolution of the complex refractive index in the near UV spectral region in ageing secondary organic aerosol, Atmos. Chem. Phys. Discuss., 14, 4149-4187, doi:10.5194/acpd-14-4149-2014, 2014.

Gao, S., Keywood, M., Ng, N. L., Surratt, J., Varutbangkul, V., Bahreini, R., Flagan, R. C., and Seinfeld, J. H.: Low-molecularweight and oligomeric components in secondary organic aerosol from the ozonolysis of cycloalkenes and alpha-pinene, J. Phys. Chem. A, 108, 10147-10164, doi:10.1021/jp047466e, 2004a.

Gao, S., Ng, N. L., Keywood, M., Varutbangkul, V., Bahreini, R., Nenes, A., He, J., Yoo, K. Y., Beauchamp, J. L., Hodyss, R. P., Flagan, R. C., and Seinfeld, J. H.: Particle phase acidity and oligomer formation in secondary organic aerosol, Environ. Sci. Technol., 38, 6582-6589, 2004b.

George, I. J. and Abbatt, J. P. D.: Chemical evolution of secondary organic aerosol from $\mathrm{OH}$-initiated heterogeneous oxidation, Atmos. Chem. Phys., 10, 5551-5563, doi:10.5194/acp-10-55512010, 2010.

Goldstein, A. H. and Galbally, I. E.: Known and unexplored organic constituents in the Earth's atmosphere, Geochim. Cosmochim. Ac., 73, A449-A449, 2009.

Griffin, R. J., Cocker III, D. R., Seinfeld, J. H., and Dabdub, D.: Estimate of global atmospheric organic aerosol from oxidation of biogenic hydrocarbons, Geophys. Res. Lett., 26, 2721-2724, 1999.
Guenther, A., Hewitt, C. N., Erickson, D., Fall, R., Geron, C., Graedel, T., Harley, P., Klinger, L., Lerdau, M., Mckay, W. A., Pierce, T., Scholes, B., Steinbrecher, R., Tallamraju, R., Taylor, J., and Zimmerman, P.: A global model of natural volatile organic compound emissions, J. Geophys. Res., 100, 8873-8892, 1995.

Hallquist, M., Wenger, J. C., Baltensperger, U., Rudich, Y., Simpson, D., Claeys, M., Dommen, J., Donahue, N. M., George, C., Goldstein, A. H., Hamilton, J. F., Herrmann, H., Hoffmann, T., Iinuma, Y., Jang, M., Jenkin, M. E., Jimenez, J. L., KiendlerScharr, A., Maenhaut, W., McFiggans, G., Mentel, Th. F., Monod, A., Prévôt, A. S. H., Seinfeld, J. H., Surratt, J. D., Szmigielski, R., and Wildt, J.: The formation, properties and impact of secondary organic aerosol: current and emerging issues, Atmos. Chem. Phys., 9, 5155-5236, doi:10.5194/acp-9-51552009, 2009.

Hatch, C. D., Gierlus, K. M., Schuttlefield, J. D., and Grassian, V. H.: Water adsorption and cloud condensation nuclei activity of calcite and calcite coated with model humic and fulvic acids, Atmos. Environ., 42, 5672-5684, doi:10.1016/j.atmosenv.2008.03.005, 2008.

Haywood, J. M. and Ramaswamy, V.: Global sensitivity studies of the direct radiative forcing due to anthropogenic sulfate and black carbon aerosols, J. Geophys. Res., 103, 6043-6058, 1998.

Hegg, D., Larson, T., and Yuen, P. F.: A theoretical-study of the effect of relative-humidity on light-scattering by tropospheric aerosols, J. Geophys. Res.-Atmos., 98, 18435-18439, doi:10.1029/93jd01928, 1993.

Henry, K. M. and Donahue, N. M.: Photochemical aging of $\alpha$-pinene secondary organic aerosol: effects of $\mathrm{OH}$ radical sources and photolysis, J. Phys. Chem. A, 116, 5932-5940, doi:10.1021/jp210288s, 2012.

Hoyle, C. R., Myhre, G., Berntsen, T. K., and Isaksen, I. S. A.: Anthropogenic influence on SOA and the resulting radiative forcing, Atmos. Chem. Phys., 9, 2715-2728, doi:10.5194/acp-9-27152009, 2009.

Jang, M. and Kamens, R. M.: A thermodynamic approach for modeling partitioning of semivolatile organic compounds on atmospheric particulate matter: humidity effects, Environ. Sci. Technol., 32, 1237-1243, doi:10.1021/es970773w, 1998.

Jimenez, J. L., Canagaratna, M. R., Donahue, N. M., Prevot, A. S. H., Zhang, Q., Kroll, J. H., DeCarlo, P. F., Allan, J. D., Coe, H., Ng, N. L., Aiken, A. C., Docherty, K. S., Ulbrich, I. M., Grieshop, A. P., Robinson, A. L., Duplissy, J., Smith, J. D., Wilson, K. R., Lanz, V. A., Hueglin, C., Sun, Y. L., Tian, J., Laaksonen, A., Raatikainen, T., Rautiainen, J., Vaattovaara, P., Ehn, M., Kulmala, M., Tomlinson, J. M., Collins, D. R., Cubison, M. J., E., Dunlea, J., Huffman, J. A., Onasch, T. B., Alfarra, M. R., Williams, P. I., Bower, K., Kondo, Y., Schneider, J., Drewnick, F., Borrmann, S., Weimer, S., Demerjian, K., Salcedo, D., Cottrell, L., Griffin, R., Takami, A., Miyoshi, T., Hatakeyama, S., Shimono, A., Sun, J. Y., Zhang, Y. M., Dzepina, K., Kimmel, J. R., Sueper, D., Jayne, J. T., Herndon, S. C., Trimborn, A. M., Williams, L. R., Wood, E. C., Middlebrook, A. M., Kolb, C. E., Baltensperger, U., and Worsnop, D. R.: Evolution of Organic Aerosols in the Atmosphere, Science, 326, 1525-1529, doi:10.1126/science.1180353, 2009.

Kanakidou, M., Seinfeld, J. H., Pandis, S. N., Barnes, I., Dentener, F. J., Facchini, M. C., Van Dingenen, R., Ervens, B., 
Nenes, A., Nielsen, C. J., Swietlicki, E., Putaud, J. P., Balkanski, Y., Fuzzi, S., Horth, J., Moortgat, G. K., Winterhalter, R., Myhre, C. E. L., Tsigaridis, K., Vignati, E., Stephanou, E. G., and Wilson, J.: Organic aerosol and global climate modelling: a review, Atmos. Chem. Phys., 5, 1053-1123, doi:10.5194/acp-51053-2005, 2005.

Kannosto, J., Yli-Pirila, P., Hao, L. Q., Leskinen, J., Jokiniemi, J., Makela, J. M., Joutsensaari, J., Laaksonen, A., Worsnop, D. R., Keskinen, J., and Virtanen, A.: Bounce characteristics of $\alpha$ pinene-derived SOA particles with implications to physical phase, Boreal Environ. Res., 18, 329-340, 2013.

Katrib, Y., Martin, S. T., Rudich, Y., Davidovits, P., Jayne, J. T., and Worsnop, D. R.: Density changes of aerosol particles as a result of chemical reaction, Atmos. Chem. Phys., 5, 275-291, doi:10.5194/acp-5-275-2005, 2005.

Kavouras, I. G., Mihalopoulos, N., and Stephanou, E. G.: Formation of atmospheric particles from organic acids produced by forests, Nature, 395, 683-686, 1998.

Kavouras, I. G., Mihalopoulos, N., and Stephanou, E. G.: Formation and gas/particle partitioning of monoterpenes photooxidation products over forests, Geophys. Res. Lett., 26, 55-58, doi:10.1029/1998g1900251, 1999.

Kim, H. and Paulson, S. E.: Real refractive indices and volatility of secondary organic aerosol generated from photooxidation and ozonolysis of limonene, $\alpha$-pinene and toluene, Atmos. Chem. Phys., 13, 7711-7723, doi:10.5194/acp-13-7711-2013, 2013.

Kim, H., Barkey, B., and Paulson, S. E.: Real refractive indices of $\alpha$ - and $\beta$-pinene and toluene secondary organic aerosols generated from ozonolysis and photo-oxidation, J. Geophys. Res., 115, D24212, doi:10.1029/2010JD014549, 2010.

Kinne, S., Lohmann, U., Feichter, J., Schulz, M., Timmreck, C., Ghan, S., Easter, R., Chin, M., Ginoux, P., Takemura, T., Tegen, I., Koch, D., Herzog, M., Penner, J., Pitari, G., Holben, B., Eck, T., Smirnov, A., Dubovik, O., Slutsker, I., Tanre, D., Torres, O., Mishchenko, M., Geogdzhayev, I., Chu, D. A., and Kaufman, Y.: Monthly averages of aerosol properties: a global comparison among models, satellite data, and AERONET ground data, J. Geophys. Res.-Atmos., 108, 4634, doi:10.1029/2001jd001253, 2003.

Koop, T., Bookhold, J., Shiraiwa, M., and Pöschl, U.: Glass transition and phase state of organic compounds: dependency on molecular properties and implications for secondary organic aerosols in the atmosphere, Phys. Chem. Chem. Phys., 13, 19238-19255, doi:10.1039/C1CP22617G, 2011.

Kroll, J. H. and Seinfeld, J. H.: Chemistry of secondary organic aerosol: formation and evolution of low-volatility organics in the atmosphere, Atmos. Environ., 42, 3593-3624, doi:10.1016/j.atmosenv.2008.01.003, 2008.

Lambe, A. T., Onasch, T. B., Massoli, P., Croasdale, D. R., Wright, J. P., Ahern, A. T., Williams, L. R., Worsnop, D. R., Brune, W. H., and Davidovits, P.: Laboratory studies of the chemical composition and cloud condensation nuclei $(\mathrm{CCN})$ activity of secondary organic aerosol (SOA) and oxidized primary organic aerosol (OPOA), Atmos. Chem. Phys., 11, 8913-8928, doi:10.5194/acp11-8913-2011, 2011.

Lambe, A. T., Cappa, C. D., Massoli, P., Onasch, T. B., Forestieri, S. D., Martin, A. T., Cummings, M. J., Croasdale, D. R., Brune, W. H., Worsnop, D. R., and Davidovits, P.: Relationship between oxidation level and optical properties of secondary organic aerosol, Environ. Sci. Technol., 47, 63496357, doi:10.1021/es401043j, 2013.

Lang-Yona, N., Rudich, Y., Mentel, Th. F., Bohne, A., Buchholz, A., Kiendler-Scharr, A., Kleist, E., Spindler, C., Tillmann, R., and Wildt, J.: The chemical and microphysical properties of secondary organic aerosols from Holm Oak emissions, Atmos. Chem. Phys., 10, 7253-7265, doi:10.5194/acp-10-7253-2010, 2010.

Liu, P., Zhang, Y., and Martin, S. T.: Complex refractive indices of thin films of secondary organic materials by spectroscopic ellipsometry from 220 to $1200 \mathrm{~nm}$, Environ. Sci. Technol., 47, 13594-13601, doi:10.1021/es403411e, 2013.

Liu, Y. G. and Daum, P. H.: Relationship of refractive index to mass density and self-consistency of mixing rules for multicomponent mixtures like ambient aerosols, J. Aerosol Sci., 39, 974-986, doi:10.1016/j.jaerosci.2008.06.006, 2008.

Lohmann, U. and Feichter, J.: Global indirect aerosol effects: a review, Atmos. Chem. Phys., 5, 715-737, doi:10.5194/acp-5-7152005, 2005.

Martin, S. T.: Phase transitions of aqueous atmospheric particles, Chem. Rev., 100, 3403-3453, doi:10.1021/cr990034t, 2000.

Martin, S. T., Andreae, M. O., Althausen, D., Artaxo, P., Baars, H., Borrmann, S., Chen, Q., Farmer, D. K., Guenther, A., Gunthe, S. S., Jimenez, J. L., Karl, T., Longo, K., Manzi, A., Müller, T., Pauliquevis, T., Petters, M. D., Prenni, A. J., Pöschl, U., Rizzo, L. V., Schneider, J., Smith, J. N., Swietlicki, E., Tota, J., Wang, J., Wiedensohler, A., and Zorn, S. R.: An overview of the Amazonian Aerosol Characterization Experiment 2008 (AMAZE08), Atmos. Chem. Phys., 10, 11415-11438, doi:10.5194/acp10-11415-2010, 2010.

Massoli, P., Lambe, A. T., Ahern, A. T., Williams, L. R., Ehn, M., Mikkilä, J., Canagaratna, M. R., Brune, W. H., Onasch, T. B., Jayne, J. T., Petäjä, T., Kulmala, M., Laaksonen, A., Kolb, C. E., Davidovits, P., and Worsnop, D. R.: Relationship between aerosol oxidation level and hygroscopic properties of laboratory generated secondary organic aerosol (SOA) particles, Geophys. Res. Lett., 37, L24801, doi:10.1029/2010GL045258, 2010.

Matsumoto, K., Tanaka, H., Nagao, I., and Ishizaka, Y.: Contribution of particulate sulfate and organic carbon to cloud condensation nuclei in the marine atmosphere, Geophys. Res. Lett., 24, 655-658, doi:10.1029/97g100541, 1997.

McFiggans, G., Artaxo, P., Baltensperger, U., Coe, H., Facchini, M. C., Feingold, G., Fuzzi, S., Gysel, M., Laaksonen, A., Lohmann, U., Mentel, T. F., Murphy, D. M., O’Dowd, C. D., Snider, J. R., and Weingartner, E.: The effect of physical and chemical aerosol properties on warm cloud droplet activation, Atmos. Chem. Phys., 6, 2593-2649, doi:10.5194/acp-6-25932006, 2006.

McIntire, T. M., Ryder, O. S., Gassman, P. L., Zhu, Z., Ghosal, S., and Finlayson-Pitts, B. J.: Why ozonolysis may not increase the hydrophilicity of particles, Atmos. Environ., 44, 939-944, doi:10.1016/j.atmosenv.2009.11.009, 2010.

Mei, F., Setyan, A., Zhang, Q., and Wang, J.: CCN activity of organic aerosols observed downwind of urban emissions during CARES, Atmos. Chem. Phys., 13, 12155-12169, doi:10.5194/acp-13-12155-2013, 2013.

Meyer, N. K., Duplissy, J., Gysel, M., Metzger, A., Dommen, J., Weingartner, E., Alfarra, M. R., Prevot, A. S. H., Fletcher, C., Good, N., McFiggans, G., Jonsson, Å. M., Hallquist, M., Bal- 
tensperger, U., and Ristovski, Z. D.: Analysis of the hygroscopic and volatile properties of ammonium sulphate seeded and unseeded SOA particles, Atmos. Chem. Phys., 9, 721-732, doi:10.5194/acp-9-721-2009, 2009.

Mikhailov, E., Vlasenko, S., Martin, S. T., Koop, T., and Pöschl, U.: Amorphous and crystalline aerosol particles interacting with water vapor: conceptual framework and experimental evidence for restructuring, phase transitions and kinetic limitations, Atmos. Chem. Phys., 9, 9491-9522, doi:10.5194/acp-9-9491-2009, 2009.

Moise, T. and Rudich, Y.: Reactive uptake of ozone by aerosol-associated unsaturated fatty acids: kinetics, mechanism, and products, J. Phys. Chem. A, 106, 6469-6476, doi:10.1021/jp025597e, 2002.

Moussa, S. G., McIntire, T. M., Szőri, M., Roeselová, M., Tobias, D. J., Grimm, R. L., Hemminger, J. C., and FinlaysonPitts, B. J.: Experimental and theoretical characterization of adsorbed water on self-assembled monolayers: understanding the interaction of water with atmospherically relevant surfaces $\dagger, \mathrm{J}$. Phys. Chem. A, 113, 2060-2069, doi:10.1021/jp808710n, 2009.

Müller, T., Laborde, M., Kassell, G., and Wiedensohler, A.: Design and performance of a three-wavelength LED-based total scatter and backscatter integrating nephelometer, Atmos. Meas. Tech., 4, 1291-1303, doi:10.5194/amt-4-1291-2011, 2011.

Müller, L., Reinnig, M.-C., Naumann, K. H., Saathoff, H., Mentel, T. F., Donahue, N. M., and Hoffmann, T.: Formation of 3-methyl-1,2,3-butanetricarboxylic acid via gas phase oxidation of pinonic acid - a mass spectrometric study of SOA aging, Atmos. Chem. Phys., 12, 1483-1496, doi:10.5194/acp-12-14832012, 2012.

Murray, B. J.: Inhibition of ice crystallisation in highly viscous aqueous organic acid droplets, Atmos. Chem. Phys., 8, 54235433, doi:10.5194/acp-8-5423-2008, 2008.

Nakayama, T., Matsumi, Y., Sato, K., Imamura, T., Yamazaki, A., and Uchiyama, A.: Laboratory studies on optical properties of secondary organic aerosols generated during the photooxidation of toluene and the ozonolysis of alpha-pinene, J. Geophys. Res.Atmos., 115, D24204, doi:10.1029/2010jd014387, 2010.

Nakayama, T., Sato, K., Matsumi, Y., Imamura, T., Yamazaki, A., and Uchiyama, A.: Wavelength dependence of refractive index of secondary organic aerosols generated during the ozonolysis and photooxidation of $\alpha$-pinene, Sola, 8, 119-123, doi:10.2151/sola.2012-030, 2012.

Nakayama, T., Sato, K., Matsumi, Y., Imamura, T., Yamazaki, A., and Uchiyama, A.: Wavelength and $\mathrm{NO}_{\mathrm{x}}$ dependent complex refractive index of SOAs generated from the photooxidation of toluene, Atmos. Chem. Phys., 13, 531-545, doi:10.5194/acp-13531-2013, 2013.

Nemesure, S., Wagener, R., and Schwartz, S. E.: Direct shortwave forcing of climate by the anthropogenic sulfate aerosol: sensitivity to particle size, composition, and relative humidity, J. Geophys. Res.-Atmos., 100, 26105-26116, doi:10.1029/95jd02897, 1995.

Ng, N. L., Canagaratna, M. R., Zhang, Q., Jimenez, J. L., Tian, J., Ulbrich, I. M., Kroll, J. H., Docherty, K. S., Chhabra, P. S., Bahreini, R., Murphy, S. M., Seinfeld, J. H., Hildebrandt, L., Donahue, N. M., DeCarlo, P. F., Lanz, V. A., Prévôt, A. S. H., Dinar, E., Rudich, Y., and Worsnop, D. R.: Organic aerosol components observed in Northern Hemispheric datasets from
Aerosol Mass Spectrometry, Atmos. Chem. Phys., 10, 46254641, doi:10.5194/acp-10-4625-2010, 2010.

Novakov, T. and Penner, J. E.: Large contribution of organic aerosols to cloud-condensation-nuclei, Nature, 365, 823-826, doi:10.1038/365823a0, 1993.

O'Donnell, D., Tsigaridis, K., and Feichter, J.: Estimating the direct and indirect effects of secondary organic aerosols using ECHAM5-HAM, Atmos. Chem. Phys., 11, 8635-8659, doi:10.5194/acp-11-8635-2011, 2011.

Orr Jr., C., Hurd, F. K., and Corbett, W. J.: Aerosol size and relative humidity, J. Coll. Sci. Imp. U. Tok., 13, 472-482, doi:10.1016/0095-8522(58)90055-2, 1958.

Pajunoja, A., Malila, J., Hao, L. Q., Joutsensaari, J., Lehtinen, K. E. J., and Virtanen, A.: Estimating the viscosity range of SOA particles based on their coalescence time, Aerosol Sci. Tech., 48, I-IV, doi:10.1080/02786826.2013.870325, 2014.

Pankow, J. F., Storey, J. M. E., and Yamasaki, H.: Effects of relativehumidity on gas-particle partitioning of semivolatile organiccompounds to urban particulate matter, Environ. Sci. Technol., 27, 2220-2226, doi:10.1021/es00047a032, 1993.

Pankow, J. F. and Asher, W. E.: SIMPOL.1: a simple group contribution method for predicting vapor pressures and enthalpies of vaporization of multifunctional organic compounds, Atmos. Chem. Phys., 8, 2773-2796, doi:10.5194/acp-8-27732008, 2008.

Paulson, S. E., Chung, M., Sen, A. D., and Orzechowska, G.: Measurement of $\mathrm{OH}$ radical formation from the reaction of ozone with several biogenic alkenes, J. Geophys. Res.-Atmos., 103, 25533-25539, doi:10.1029/98jd01951, 1998.

Pere, J. C., Mallet, M., Pont, V., and Bessagnet, B.: Impact of aerosol direct radiative forcing on the radiative budget, surface heat fluxes, and atmospheric dynamics during the heat wave of summer 2003 over western Europe: a modeling study, J. Geophys. Res.-Atmos., 116, D23119, doi:10.1029/2011jd016240, 2011.

Perraud, V., Bruns, E. A., Ezell, M. J., Johnson, S. N., Yu, Y., Alexander, M. L., Zelenyuk, A., Imre, D., Chang, W. L., Dabdub, D., Pankow, J. F., and Finlayson-Pitts, B. J.: Nonequilibrium atmospheric secondary organic aerosol formation and growth, P. Natl. Acad. Sci. USA, 109, 2836-2841, doi:10.1073/pnas.1119909109, 2012.

Petters, M. D. and Kreidenweis, S. M.: A single parameter representation of hygroscopic growth and cloud condensation nucleus activity, Atmos. Chem. Phys., 7, 1961-1971, doi:10.5194/acp-71961-2007, 2007.

Prenni, A. J., DeMott, P. J., and Kreidenweis, S. M.: Water uptake of internally mixed particles containing ammonium sulfate and dicarboxylic acids, Atmos. Environ., 37, 4243-4251, 2003.

Qi, L.: Can secondary organic aerosol formed in an atmospheric simulation chamber continuously age?, Atmos. Environ., 44, 2990-2996, 2010.

Qi, L., Nakao, S., and Cocker, D. R.: Aging of secondary organic aerosol from $\alpha$-pinene ozonolysis: roles of hydroxyl and nitrate radicals, J. Air Waste Manage., 62, 1359-1369, doi:10.1080/10962247.2012.712082, 2012.

Redmond, H. and Thompson, J. E.: Evaluation of a quantitative structure-property relationship (QSPR) for predicting mid-visible refractive index of secondary organic 
aerosol (SOA), Phys. Chem. Chem. Phys., 13, 6872-6882, doi:10.1039/c0cp02270e, 2011.

Reinhardt, A., Emmenegger, C., Gerrits, B., Panse, C., Dommen, J., Baltensperger, U., Zenobi, R., and Kalberer, M.: Ultrahigh mass resolution and accurate mass measurements as a tool to characterize oligomers in secondary organic aerosols, Anal. Chem., 79, 4074-4082, doi:10.1021/ac062425v, 2007.

Renbaum-Wolff, L., Grayson, J. W., Bateman, A. P., Kuwata, M., Sellier, M., Murray, B. J., Shilling, J. E., Martin, S. T., and Bertram, A. K.: Viscosity of $\alpha$-pinene secondary organic material and implications for particle growth and reactivity, P. Natl. Acad. Sci. USA, 110, 8014-8019, doi:10.1073/pnas.1219548110, 2013.

Rickards, A. M. J., Miles, R. E. H., Davies, J. F., Marshall, F. H., and Reid, J. P.: Measurements of the Sensitivity of Aerosol Hygroscopicity and the $\kappa$ Parameter to the O/C Ratio, J. Phys. Chem. A, 117, 14120-14131, doi:10.1021/jp407991n, 2013.

RiveraCarpio, C. A., Corrigan, C. E., Novakov, T., Penner, J. E., Rogers, C. F., and Chow, J. C.: Derivation of contributions of sulfate and carbonaceous aerosols to cloud condensation nuclei from mass size distributions, J. Geophys. Res.-Atmos., 101, 19483-19493, doi:10.1029/95jd01077, 1996.

Roth, C. M., Goss, K. U., and Schwarzenbach, R. P.: Sorption of a diverse set of organic vapors to urban aerosols, Environ. Sci. Technol., 39, 6638-6643, doi:10.1021/es0503837, 2005.

Rudich, Y., Donahue, N. M., and Mentel, T. F.: Aging of organic aerosol: bridging the gap between laboratory and field studies, Annu. Rev. Phys. Chem., Annual Reviews, Palo Alto, 321-352, 2007

Saathoff, H., Naumann, K.-H., Schnaiter, M., Schöck, W., Möhler, O., Schurath, U., Weingartner, E., Gysel, M., and Baltensperger, U.: Coating of soot and $\left(\mathrm{NH}_{4}\right) 2 \mathrm{SO}_{4}$ particles by ozonolysis products of $[\alpha]$-pinene, J. Aerosol Sci., 34, 12971321, 2003.

Saathoff, H., Naumann, K.-H., Möhler, O., Jonsson, Å. M., Hallquist, M., Kiendler-Scharr, A., Mentel, Th. F., Tillmann, R., and Schurath, U.: Temperature dependence of yields of secondary organic aerosols from the ozonolysis of $\alpha$-pinene and limonene, Atmos. Chem. Phys., 9, 1551-1577, doi:10.5194/acp-9-15512009, 2009.

Sato, K., Takami, A., Kato, Y., Seta, T., Fujitani, Y., Hikida, T., Shimono, A., and Imamura, T.: AMS and LC/MS analyses of SOA from the photooxidation of benzene and 1,3,5-trimethylbenzene in the presence of $\mathrm{NO}_{\mathrm{x}}$ : effects of chemical structure on SOA aging, Atmos. Chem. Phys., 12, 4667-4682, doi:10.5194/acp-124667-2012, 2012.

Saukko, E., Lambe, A. T., Massoli, P., Koop, T., Wright, J. P., Croasdale, D. R., Pedernera, D. A., Onasch, T. B., Laaksonen, A., Davidovits, P., Worsnop, D. R., and Virtanen, A.: Humiditydependent phase state of SOA particles from biogenic and anthropogenic precursors, Atmos. Chem. Phys., 12, 7517-7529, doi:10.5194/acp-12-7517-2012, 2012.

Saunders, S. M., Jenkin, M. E., Derwent, R. G., and Pilling, M. J.: Protocol for the development of the Master Chemical Mechanism, MCM v3 (Part A): tropospheric degradation of nonaromatic volatile organic compounds, Atmos. Chem. Phys., 3, 161-180, doi:10.5194/acp-3-161-2003, 2003.
Saxena, P., Hildemann, L. M., McMurry, P. H., and Seinfeld, J. H.: Organics alter hygroscopic behavior of atmospheric particles, J. Geophys. Res., 100, 18755-18770, 1995.

Schnaiter, M., Horvath, H., Möhler, O., Naumann, K.-H., Saathoff, H., and Schöck, O. W.: UV-VIS-NIR spectral optical properties of soot and soot-containing aerosols, J. Aerosol Sci., 34, 1421-1444, 2003.

Semeniuk, T. A., Wise, M. E., Martin, S. T., Russell, L. M., and Buseck, P. R.: Water uptake characteristics of individual atmospheric particles having coatings, Atmos. Environ., 41, 62256235, 2007.

Shilling, J. E., Chen, Q., King, S. M., Rosenoern, T., Kroll, J. H., Worsnop, D. R., McKinney, K. A., and Martin, S. T.: Particle mass yield in secondary organic aerosol formed by the dark ozonolysis of $\alpha$-pinene, Atmos. Chem. Phys., 8, 2073-2088, doi:10.5194/acp-8-2073-2008, 2008.

Shiraiwa, M., Yee, L. D., Schilling, K. A., Loza, C. L., Craven, J. S., Zuend, A., Ziemann, P. J., and Seinfeld, J. H.: Size distribution dynamics reveal particle-phase chemistry in organic aerosol formation, P. Natl. Acad. Sci. USA, 110, 11746-11750, doi:10.1073/pnas.1307501110, 2013.

Suda, S. R., Petters, M. D., Matsunaga, A., Sullivan, R. C., Ziemann, P. J., and Kreidenweis, S. M.: Hygroscopicity frequency distributions of secondary organic aerosols, J. Geophys. Res.Atmos., 117, D04207, doi:10.1029/2011jd016823, 2012.

Tolocka, M. P., Jang, M., Ginter, J. M., Cox, F. J., Kamens, R. M., and Johnston, M. V.: Formation of oligomers in secondary organic aerosol, Environ. Sci. Technol., 38, 1428-1434, doi:10.1021/es035030r, 2004.

Tolocka, M. P., Heaton, K. J., Dreyfus, M. A., Wang, S. Y., Zordan, C. A., Saul, T. D., and Johnston, M. V.: Chemistry of particle inception and growth during alpha-pinene ozonolysis, Environ. Sci. Technol., 40, 1843-1848, doi:10.1021/es051926f, 2006.

Tost, H. and Pringle, K. J.: Improvements of organic aerosol representations and their effects in large-scale atmospheric models, Atmos. Chem. Phys., 12, 8687-8709, doi:10.5194/acp-12-86872012, 2012.

Tritscher, T., Dommen, J., DeCarlo, P. F., Gysel, M., Barmet, P. B., Praplan, A. P., Weingartner, E., Prévôt, A. S. H., Riipinen, I., Donahue, N. M., and Baltensperger, U.: Volatility and hygroscopicity of aging secondary organic aerosol in a smog chamber, Atmos. Chem. Phys., 11, 11477-11496, doi:10.5194/acp-1111477-2011, 2011.

Turpin, B. J. and Huntzicker, J. J.: Identification of secondary organic aerosol episodes and quantitation of primary and secondary organic aerosol concentrations during scaqs, Atmos. Environ., 29, 3527-3544, doi:10.1016/1352-2310(94)00276-q, 1995.

Vaden, T. D., Song, C., Zaveri, R. A., Imre, D., and Zelenyuk, A.: Morphology of mixed primary and secondary organic particles and the adsorption of spectator organic gases during aerosol formation, P. Natl. Acad. Sci. USA, 107, 6658-6663, doi:10.1073/pnas.0911206107, 2010.

Vaden, T. D., Imre, D., Beránek, J., Shrivastava, M., and Zelenyuk, A.: Evaporation kinetics and phase of laboratory and ambient secondary organic aerosol, P. Natl. Acad. Sci. USA, 108, 2190-2195, doi:10.1073/pnas.1013391108, 2011.

Virtanen, A., Kannosto, J., Kuuluvainen, H., Arffman, A., Joutsensaari, J., Saukko, E., Hao, L., Yli-Pirilä, P., Tiitta, P., Holopainen, J. K., Keskinen, J., Worsnop, D. R., Smith, J. N., 
and Laaksonen, A.: Bounce behavior of freshly nucleated biogenic secondary organic aerosol particles, Atmos. Chem. Phys., 11, 8759-8766, doi:10.5194/acp-11-8759-2011, 2011.

Wang, J., Doussin, J. F., Perrier, S., Perraudin, E., Katrib, Y., Pangui, E., and Picquet-Varrault, B.: Design of a new multi-phase experimental simulation chamber for atmospheric photosmog, aerosol and cloud chemistry research, Atmos. Meas. Tech., 4, 2465-2494, doi:10.5194/amt-4-2465-2011, 2011.

Warren, B., Austin, R. L., and Cocker III, D. R.: Temperature dependence of secondary organic aerosol, Atmos. Environ., 43, 35483555, 2009.

Weingartner, E., Saathoff, H., Schnaiter, M., Streit, N., Bitnar, B., and Baltensperger, U.: Absorption of light by soot particles: determination of the absorption coefficient by means of aethalometers, J. Aerosol Sci., 34, 1445-1463, 2003.

Wex, H., Petters, M. D., Carrico, C. M., Hallbauer, E., Massling, A., McMeeking, G. R., Poulain, L., Wu, Z., Kreidenweis, S. M., and Stratmann, F.: Towards closing the gap between hygroscopic growth and activation for secondary organic aerosol: Part $1-\mathrm{Ev}-$ idence from measurements, Atmos. Chem. Phys., 9, 3987-3997, doi:10.5194/acp-9-3987-2009, 2009.

Wong, J. P. S., Lee, A. K. Y., Slowik, J. G., Cziczo, D. J., Leaitch, W. R., Macdonald, A., and Abbatt, J. P. D.: Oxidation of ambient biogenic secondary organic aerosol by hydroxyl radicals: Effects on cloud condensation nuclei activity, Geophys. Res. Lett., 38, L22805, 10.1029/2011GL049351, 2011.

Yasmeen, F., Vermeylen, R., Maurin, N., Perraudin, E., Doussin, J. F., and Claeys, M.: Characterisation of tracers for aging of alpha-pinene secondary organic aerosol using liquid chromatography/negative ion electrospray ionisation mass spectrometry, Environ. Chem., 9, 236-246, doi:10.1071/en11148, 2012.

Yu, J. Z., Griffin, R. J., Cocker, D. R., Flagan, R. C., Seinfeld, J. H., and Blanchard, P.: Observation of gaseous and particulate products of monoterpene oxidation in forest atmospheres, Geophys. Res. Lett., 26, 1145-1148, doi:10.1029/1999g1900169, 1999.
Zaveri, R. A., Barnard, J. C., Easter, R. C., Riemer, N., and West, M.: Particle-resolved simulation of aerosol size, composition, mixing state, and the associated optical and cloud condensation nuclei activation properties in an evolving urban plume, J. Geophys. Res.-Atmos., 115, D17210, doi:10.1029/2009jd013616, 2010.

Zelenyuk, A., Yang, J., Song, C., Zaveri, R. A., and Imre, D.: A new real-time method for determining particles' sphericity and density: application to secondary organic aerosol formed by ozonolysis of $\alpha$-pinene, Environ. Sci. Technol., 42, 8033-8038, doi:10.1021/es8013562, 2008.

Zhang, Q., Jimenez, J. L., Canagaratna, M. R., Allan, J. D., Coe, H., Ulbrich, I., Alfarra, M. R., Takami, A., Middlebrook, A. M., Sun, Y. L., Dzepina, K., Dunlea, E., Docherty, K., DeCarlo, P. F., Salcedo, D., Onasch, T., Jayne, J. T., Miyoshi, T., Shimono, A., Hatakeyama, S., Takegawa, N., Kondo, Y., Schneider, J., Drewnick, F., Borrmann, S., Weimer, S., Demerjian, K., Williams, P., Bower, K., Bahreini, R., Cottrell, L., Griffin, R. J., Rautiainen, J., Sun, J. Y., Zhang, Y. M., and Worsnop, D. R.: Ubiquity and dominance of oxygenated species in organic aerosols in anthropogenically-influenced Northern Hemisphere midlatitudes, Geophys. Res. Lett., 34, L13801, doi:10.1029/2007g1029979, 2007.

Ziemann, P. J. and Atkinson, R.: Kinetics, products, and mechanisms of secondary organic aerosol formation, Chem. Soc. Rev., 41, 6582-6605, doi:10.1039/C2CS35122F, 2012.

Zobrist, B., Soonsin, V., Luo, B. P., Krieger, U. K., Marcolli, C., Peter, T., and Koop, T.: Ultra-slow water diffusion in aqueous sucrose glasses, Phys. Chem. Chem. Phys., 13, 3514-3526, doi:10.1039/c0cp01273d, 2011. 